\title{
Reassembly of the Dharwar and Bastar cratons at ca. 1 Ga: Evidence from multiple tectonothermal events along the Karimnagar granulite belt and Khammam schist belt, southern India
}

\author{
Sojen Joy ${ }^{1, *}$ @ , Gert Van Der Linde $^{1}$, Asru K Choudhury ${ }^{2, * *}$, Gautam K Deb ${ }^{3}$ \\ and Sebastian TaPPE ${ }^{1,4}$ \\ ${ }^{1}$ De Beers Group Services, Exploration, Southdale, P/Bag X01, Johannesburg 2135, South Africa. \\ ${ }^{2}$ Indian Statistical Institute, Calcutta, India. \\ ${ }^{3}$ Department of Geology, Presidency University, Calcutta 700 073, India. \\ ${ }^{4}$ Department of Geology, University of Johannesburg, P.O. Box 524, Auckland Park 2006, South Africa. \\ *Corresponding author. e-mail: sojen.joy@debeersgroup.com
}

MS received 6 September 2017; revised 19 December 2017; accepted 22 December 2017;

published online 28 July 2018

The northern part of the Nellore-Khammam schist belt and the Karimnagar granulite belt, which are juxtaposed at high angle to each other have unique $\mathrm{U}-\mathrm{Pb}$ zircon age records suggesting distinctive tectonothermal histories. Plate accretion and rifting in the eastern part of the Dharwar craton and between the Dharwar and Bastar craton indicate multiple and complex events from 2600 to 500 Ma. The Khammam schist belt, the Dharwar and the Bastar craton were joined together by the end of the Archaean. The Khammam schist belt had experienced additional tectonic events at $\sim 1900$ and 1600 Ma. The Dharwar and Bastar cratons separated during development of the Pranhita-Godavari $(\mathrm{P}-\mathrm{G})$ valley basin at $\sim 1600 \mathrm{Ma}$, potentially linked to the breakup of the Columbia supercontinent and were reassembled during the Mesoproterozoic at about 1000 Ma. This amalgamation process in southern India could be associated with the formation of the Rodinia supercontinent. The Khammam schist belt and the Eastern Ghats mobile belt also show evidence for accretionary processes at around $500 \mathrm{Ma}$, which is interpreted as a record of Pan-African collisions during the Gondwana assembly. From then on, southern India, as is known today, formed an integral part of the Indian continent.

Keywords. U-Pb Zircon geochronology; Indian craton assembly and rifting; Rodinia; Columbia; $\mathrm{P}-\mathrm{G}$ valley; Eastern Ghats Mobile Belt.

\section{Introduction}

It is generally accepted that the Indian subcontinent was stabilized through accretion and

** Deceased. assembly of several Archaean nuclei, namely, the Dharwar, Aravalli-Bundelkhand, Singhbhum, and Bastar (Bhandara) cratons by c. 2.6-2.5 Ga (Radhakrishna and Naqvi 1986; Rogers 1986; Ramakrishnan and Vaidyanadhan 2008; Sharma 2009; Saha and Mazumder 2012; Jayananda et al. 


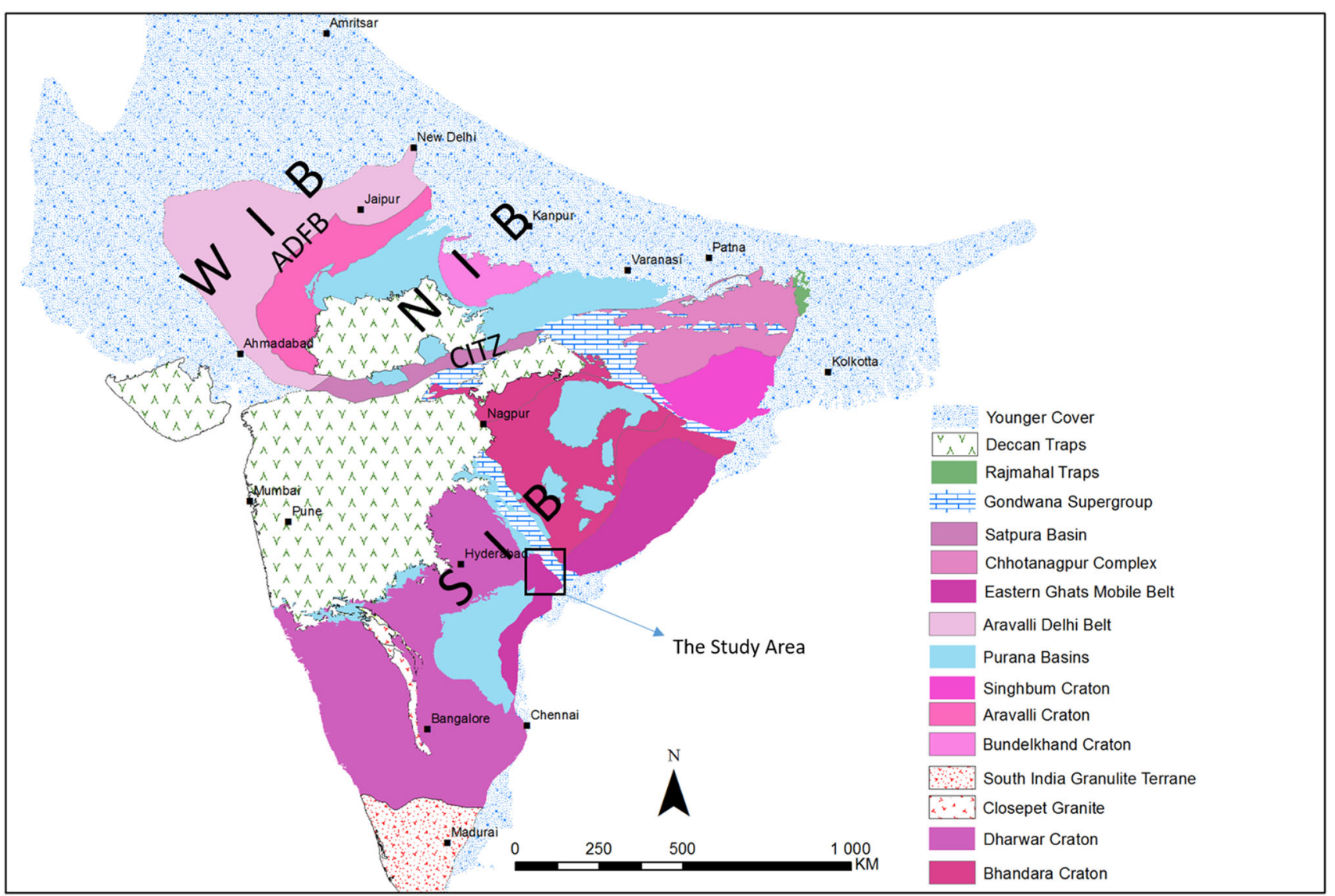

Figure 1. The regional geology of India, with the WIB (western Indian block), NIB (northern Indian block), and SIB (southern Indian block), ADFB (Aravalli-Delhi fold belt) and CITZ (Central Indian Tectonic Zone) marked after Basu and Bickford (2015).

2013). Scattered across the Indian Archaean nuclei are several unmetamorphosed and only locally or weakly deformed volcano-sedimentary successions of Proterozoic age (figure 1). These erosional remnants are referred collectively in Indian literature as the 'Purana basins' (Holland 1907). Despite generally similar sedimentological features and lithofacies, as well as a similar time span of deposition between 2.0 and $0.7 \mathrm{Ga}$, the origin and evolution of these basins are not unanimously accepted (e.g., Basu and Bickford 2015; Joy et al. 2015; Saha et al. 2016).

Recently, Basu and Bickford (2015) divided the Indian continent into three main cratonic domains (southern Indian, northern Indian, and western Indian blocks - SIB, NIB and WIB, respectively; figure 1) to more readily compare the evolution of the Purana basins within the context of supercontinent development and the tectonic evolution of the Indian Proterozoic mobile belts, including the Eastern Ghats mobile belt (EGMB), the Central Indian Tectonic Zone (CITZ), and the Aravalli-Delhi fold belt (ADFB). However, it is now well understood that the evolution of a cratonic block is constrained by the tectonic history of the constituent terranes, which differ in intensity of deformation and metamorphism. Therefore, geological and geodynamic modelling requires robust age information to assess how and when these radically different terranes had stitched into the present day cratonic configuration. Despite growing evidence of the assembly of the first supercontinent Kenorland in the Late Neoarchaean (e.g., Bradley 2011; Meert 2012; Nance and Murphy 2013; Nance et al. 2013), comparisons and correlations have only been made between the Neoarchaean development of the Slave province in North America, a major component of Kenorland, and the Dharwar craton of southern India (Bleeker 2003). Recently, a correlation of different stages of evolution of the Purana basins with breakup of Kenorland at ca. 2.0 Ga, reassembly of Kenorland fragments to form the Columbia supercontinent at around $1.8 \mathrm{Ga}$, fragmentation of Columbia at $1.3 \mathrm{Ga}$, and finally formation of Rodinia at $900 \mathrm{Ma}$ has been made (Basu and 
Bickford 2015; Saha et al. 2016 and references therein).

The tectono-stratigraphic development of the Nellore-Khammam schist belt (NKSB) in relation to global Proterozoic events, including possible links with the assembly of Columbia and its final dispersal, has been suggested by Saha et al. (2015). However, correlations between the Purana basins and the various Proterozoic mobile belts of southern India such as the Nellore-Khammam schist belt, Eastern Ghats mobile belt (EGMB) and the Karimnagar granulite belt (KGB) are unclear. Furthermore, their final incorporation into the southern Indian cratonic block (SIB) during supercontinent formation is controversially discussed (Basu and Bickford 2015).

The southern part of the SIB, comprising the western and eastern Dharwar cratons, two major Purana basins (i.e., Cuddapah basin in the south and $\mathrm{P}-\mathrm{G}$ valley basin in the north), and the Nellore-Khammam schist belt, is an ideal area to test various models of supercontinent assembly, because the constituent terranes vary widely in their geographic disposition and in their stratigraphic and tectonothermal evolution. Furthermore, the SIB is bounded to the east by the Ongole domain of the EGMB, the tectonic journey with time of which is still debated. It is noteworthy that all the above-mentioned components of the SIB are bounded by discontinuities (thrust or normal faults) along their longitudinal trends. The available information on deformation features and metamorphic history indicate that they traversed differently through space and time to amalgamate at the present position. The components of the SIB could therefore be referred to as terranes.

Here we report new LA-ICP-MS U-Pb zircon ages from rocks of the Khammam schist belt and gneisses and granites within the Karimnagar granulite belt. We put forward a comprehensive picture of evolution of the SIB in the global context.

\section{General geology}

The geology of the study area comprises of the rocks of the Dharwar craton, the Proterozoic basins classified as part of the Purana basins of Holland (1907), the Nellore-Khammam schist belt, the Ongole and Eastern Ghats domains of the Eastern Ghats Mobile Belt (figure 2).

\subsection{Dharwar craton and Purana basins}

Based on the nature and relative abundance of greenstones, gneisses and granites the Dharwar craton has been divided into the west Dharwar craton (WDC) and the east Dharwar caton (EDC), separated by the Chitradurga Shear Zone, adjoining the western side of the Closepet Granite (Rogers 1986; Ramakrishnan and Vaidyanadhan 2008). The WDC comprises (a) older gneisses ( 3.36-3.2 Ga) with TTG affinity, which have been grouped as Peninsular Gneiss-I (Balasubrhamanyan 2006) or as Peninsular Gneiss sensu stricto (Chadwick et al. 2000), (b) two generations of greenstone belts (older Sargur Group and younger Dharwar Supergroup) and late calcalkaline to potassic plutons (Chadwick et al. 2000; Jayananda et al. 2008, 2013). In contrast, the EDC is a juvenile Neoarchaean province characterized by linear belts and rafts of 2.7-2.55 Ga supracrustal units (greenstones) with coeval TTG gneisses and migmatites, and voluminous 2.56-2.50 Ga calcalkaline to potassic plutonic bodies, including the prominent Closepet Granite (Chadwick et al. 2000; Jayananda et al. 2008, 2013).

All the Purana basins formed in close spatial association with the stable cratons, and at present cover collectively about $20 \%$ of the Archaean basement (Kale and Phansalkar 1991). Outcrop in and around the NW-SE trending $\mathrm{P}-\mathrm{G}$ valley basin is marked by symmetrical disposition of Archaean to Mesozoic rocks. The Proterozoic Godavari Supergroup (Chaudhuri and Chanda 1991), an unmetamorphosed and locally weakly deformed sedimentary rock succession, is exposed in two linear belts along the southwestern and northeastern margins of the $\mathrm{P}-\mathrm{G}$ valley, separated by a linear belt of younger Gondwana rocks (220-65 Ma; Robinson 1971). The Proterozoic belts are flanked on their outer margins by granulites and gneisses (Rajesham et al. 1993; Vansutre et al. 2013); the Karimnagar granulite belt (KGB) and the gneisses of the Dharwar craton in the SW; and the Bhopalpatnam granulite belt (BGB) and gneisses of the Bastar craton in the NE. Most of the contacts among these lithologic units are faults that follow the NW-SE trend of the $\mathrm{P}-\mathrm{G}$ valley (figure 2 ). The $\mathrm{P}-\mathrm{G}$ valley basin developed along the join between the Dharwar and Bastar cratons (Naqvi and Rogers 1987) and it is referred to as a rift basin based on geophysical and stratigraphic analyses (Qureshy et al. 1968; Naqvi et al. 1974; Chaudhuri et al. 2002). However, there 


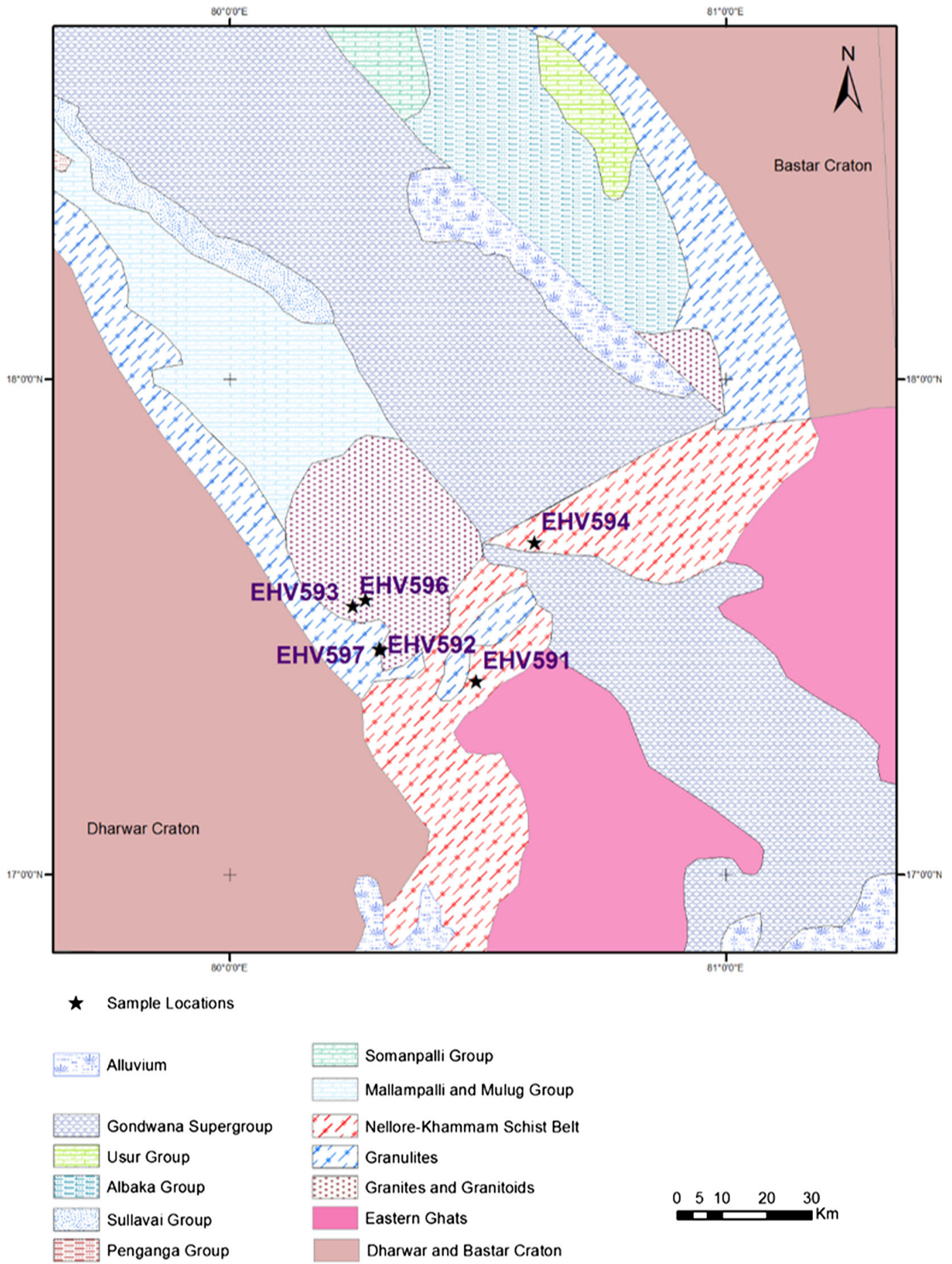

Figure 2. Geological map of the study area (modified after Chaudhuri et al. 2012) showing the location of the samples collected. The unit which was mapped as unclassified by Chaudhuri et al. (2012), was later classified as granitites and granitoids (Chaudhuri and Deb, personal communication).

are alternative tectonic models that view the evolution of the Purana basins as foreland and sag basins (e.g., Acharyya 2003; Basu and Bickford 2015).

The other Proterozoic basin of the SIB is the oval shaped Cuddapah basin, the largest among all Purana basins, which hosts $1.9 \mathrm{Ga}$ and younger unconformity-bound sedimentary rock successions (Saha and Tripathy 2012; Saha and PatranabisDeb 2014; Saha et al. 2016). The eastern part of the basin evolved into the Mesoproterozoic Nallamalai fold-thrust belt, whereas the undeformed sedimentary rock successions in the west rest unconformably on the EDC gneisses. 


\subsection{Nellore-Khammam schist belt}

The Nellore-Khammam schist belt (NKSB) is about $600 \mathrm{~km}$ long and $30-130 \mathrm{~km}$ wide (Hari Prasad et al. 2000). Its major southern extension (Nellore schist belt) separates the intracratonic Cuddapah basin to the west and the Ongole domain of the Eastern Ghats belt. In the northern extension, close to the $\mathrm{P}-\mathrm{G}$ valley basin, the belt is referred to as the Khammam schist belt (Ramam and Murty 1997; Hari Prasad et al. 2000; Okudaira et al. 2001; Saha et al. 2015), where it is sandwiched between the EGMB and the Proterozoic sedimentary succession of $\mathrm{P}-\mathrm{G}$ valley. The NKSB consists of several geologically and geochemically distinct volcano-sedimentary successions named the Vinjamuru Group, Kandra ophiolite complex (KOC), Kanigiri ophiolitic melange (KOM) and Udaigiri Group (Saha et al. 2015; Sain et al. 2017).

The Udaigiri Group is composed of predominantly greenschist facies metasedimentary rocks, whereas the Vinjamuru Group is dominantly an amphibolite facies volcano-sedimentary assemblage (Moeen 1998; Dobmeier and Raith 2003). There are two ophiolite complexes reported from the schist belt, namely the Kandra ophiolite complex (Vijaya Kumar et al. 2010) in the southern part and the Kanigiri ophiolite melange (Dharma Rao et al. 2011a) in the central part of the NKSB. The NKSB rocks show multiple deformation and metamorphism, as well as emplacement of granites and alkaline plutons (Saha et al. 2015 and references therein). Dobmeier and Raith (2003) grouped the granulite facies rocks of the Ongole domain to the NKSB and classified them as the Late Paleoproterozoic Krishna province, distinct from the Mesoproterozoic Eastern Ghats province. In contrast, Saha et al. (2015) proposed a Late Neoarchaean to Mesoproterozoic development of the NKSB independent of the Eastern Ghats belt. Although Ramakrishnan (2003) emphasised differences in tectono-stratigraphic features between the EDC greenstone belts and the Nellore-Khammam schist belt, this schist belt is often considered as the easternmost greenstone belt of the eastern Dharwar craton (Vadlamani 2010).

\subsection{Karimnagar and Bhopalpatnam granulite belts}

As mentioned earlier, the Dharwar and Bastar cratons are juxtaposed along a NW-SE trending join that was the keel of the $\mathrm{P}-\mathrm{G}$ valley basin bordered by the Karimnagar and Bhopalpatnam granulites belts (KGB and BGB) to the southwest and northeast, respectively (figure 2). These granulites occur as several enclaves and discrete narrow bands mixed with granites, granite gneisses and amphibolites (Rajesham et al. 1993; Santosh et al. 2004; Vansutre et al. 2013). We use the term KGB to include all these units in a tectono-stratigraphic sense.

Both granulite belts have characteristic length: width ratios of at least 5:1. The Karimnagar granulite belt (KGB) is interpreted as an Archaean supracrustal-granite association, metamorphosed to granulite grade, representing the suture zone between the Dharwar and Bastar cratons (Rajesham et al. 1993). The KGB is characterised by at least two phases of deformation resulting in near isoclinal refolding with axial planar cleavages and the tectonothermal events in KGB match with those in the eastern Dharwar craton (Rajesham et al. 1993). The 300-km long Bhopalpatanam granulite belt (BGP) lies on the western edge of the Bastar craton (figure 2) and is composed of two pyroxene granulites, ultramafics, quartzite, calcsilicate rocks, $\mathrm{Mg}-\mathrm{Al}$ metapelites (Vansutre and Hari 2010). The peak metamorphic condition of the high $\mathrm{Mg}-\mathrm{Al}$ granulite within the KGB is estimated as $7.5-8 \mathrm{~kb}$ at $800-840^{\circ} \mathrm{C}$ (Prakash et al. 2017).

\subsection{Eastern Ghats mobile belt}

The Eastern Ghats mobile belt (EGMB), follows the east coast of India for over $1000 \mathrm{~km}$ adjoining the Dharwar, Bastar and Singhbhum cratons to the east. The EGMB is considered as an exotic distal Grenvillian terrane, juxtaposed to the Indian continent (Chaudhuri et al. 2012). The belt is a composite of accreted linear continental and oceanic fragments of moderate to high metamorphic grade, including granulite facies rocks, which have been intruded by suites of granites, anorthosites and nepheline syenites. A terrane boundary shear zone marks the juxtaposition of the EGMB with the Indian cratons, which is of strike slip character in the north and thrust character in the west and southwest (Ratre et al. 2010). The EGMB is divided into four provinces: the Jaypore province, the Rengali province, the Eastern Ghats province and the Krishna province, each with distinct tectonothermal histories (Dobmeier and Raith 2003). The Jaypore and Rengali Province accreted to proto-India prior to the 1000 Ma assembly of Rodinia (Mukhopadhyay and Basak 2009). The Eastern Ghats province 
records high grade metamorphism and orogenesis at 980-930 Ma during amalgamation of Rodinia (Korhonen et al. 2011). The Krishna Province records collisional orogenesis and high temperature metamorphism at $1600 \mathrm{Ma}$ (Dobmeier and Raith 2003; Upadhyay et al. 2009; Henderson et al. 2013). The Krishna province is divided into the Ongole domain in the east and NSB in the west, which has been refuted by Saha et al. (2015), as discussed above in section 2.2 , considering only the Ongole domain to be part of the EGMB.

\section{Previous geochronology work}

Geochronological data from different terranes of the SIB have enhanced our knowledge about many tectonothermal events of southern India. However, a more detailed data synthesis is presented below to better understand the evolution of the SIB.

\subsection{Purana basins and eastern Dharwar craton}

The EDC is composed of number of greenstone belts of Neoarchaean age (2700-2500 Ma) (Jayananda et al. 2013 and references therein). The Closepet Granite (2513 \pm 5 Ma; Friend and Nutman 1991; Jayananda et al. 2013) and equivalents form a widespread Neoarchaean plutonic phase in the Dharwar craton. It has been suggested that emplacement of the Closepet Granite represents the amalgamation of the WDC and EDC at $\sim 2.5$ Ga (Jayananda et al. 2013).

Previous geological mapping combined with recent geochronological studies conducted on the Purana basin rocks suggest that deposition in these basins started as early as 1.9 Ga (Cuddapah basin) and basin evolution possibly ended at $<1.0$ Ga (Rasmussen et al. 2002; Ray et al. 2002; Patranabis-Deb et al. 2007; Malone et al. 2008; Das et al. 2009; Conrad et al. 2011; Sheppard et al. 2017). The Sullavai sedimentation continued until about $720 \mathrm{Ma}$ or beyond in the $\mathrm{P}-\mathrm{G}$ valley (Joy et al. 2015). However, the exact ages of the youngest sedimentary sequences in each of the basins are only poorly constrained.

The post-cratonization events in the EDC are composed of mafic dykes, kimberlites and lamproites. Protracted period of dyke activity (2.4-1.1 $\mathrm{Ga}$ ) is reported from the EDC (table 1). Age of the kimberlites cluster around $1100 \mathrm{Ma}$ and the lamproites in the Nallamalai fold belt at around 1400 Ma (Kumar et al. 2007; Chalapathi Rao et al. 2013;
Chalapathi Rao and Srivastava 2016 and references therein).

\subsection{Nellore-Khammam schist belt}

\subsubsection{Vinjamuru Group}

Sm-Nd isotope analysis from the Vinjamuru gabbro of the NKSB has yielded $2654 \pm 100 \mathrm{Ma}$ whole rock age and a 1911 $\pm 88 \mathrm{Ma}$ isochron age (Vadlamani 2010). The data has been interpreted by Vadlamani (2010) to imply that the 2.7 Ga old NKSB was intruded by MORB-type gabbro at 1911 $\mathrm{Ma}$ in response to a major extensional event along the east Dharwar craton margin. The geochemical and geochronological evidences led (Vadlamani 2010 ) to consider the volcanic events at $\sim 1.9 \mathrm{Ga}$ in the NKSB and Cuddapah basin (mafic-ultramafic sills, and gabbroic intrusives) as representing a single large anorogenic igneous event in the eastern Dharwar craton and NKSB. The andesites and rhyolites of the Vinjamuru Group have been dated through zircon $\mathrm{Pb}$ evaporation methods to be $\sim 1868$ and 1771-1791 Ma, respectively (Vadlamani et al. 2012) and the authors propose that this volcanism occurred during a major convergent orogenic event along the southeastern margin of the eastern Dharwar craton.

The Vinukonda Granite intrusive to the Vinjamuru Group is dated as $\sim 1590 \mathrm{Ma}$ (U-Pb zircon TIMS; Dobmeier et al. 2006), and represents the minimum age of the Vinjamuru Group.

Ghosh et al. (1994) report fission track and $\mathrm{K}$-Ar dates showing pegmatite events at 1600 , $\sim 1000$ and $600 \pm 100 \mathrm{Ma}$ from the Nellore mica belt (in the southern part of NKSB). The $\sim 500$ Ma event is also represented by the phengite $\mathrm{Rb}-$ $\mathrm{Sr}$ ages from mylonites of the Vinukonda granite (Dobmeier et al. 2006).

Dharma Rao et al. (2011b) report an Sm-Nd model age of $\sim 1170$ Ma from the Chimalpahad anorthosite complex in the NKSB and interpret it as an accreted arc fragment within the NKSB.

Yoshida et al. (1996) reported $1126 \mathrm{Ma}$ from metapelite from the Khammam area based on an $\mathrm{Pb}-\mathrm{Pb}$ mineral isochron. Okudaira et al. (2001), based on an Sm-Nd mineral isochron from amphibolites of the Khammam schist belt, proposed $824 \pm 53 \mathrm{Ma}$ as the age of metamorphism of the Khammam schist belt and interpreted to be the result of the tectonic accretion of the EGMB to the Dharwar-Bastar craton. Okudaira et al. (2001) also report another thermal event from the 


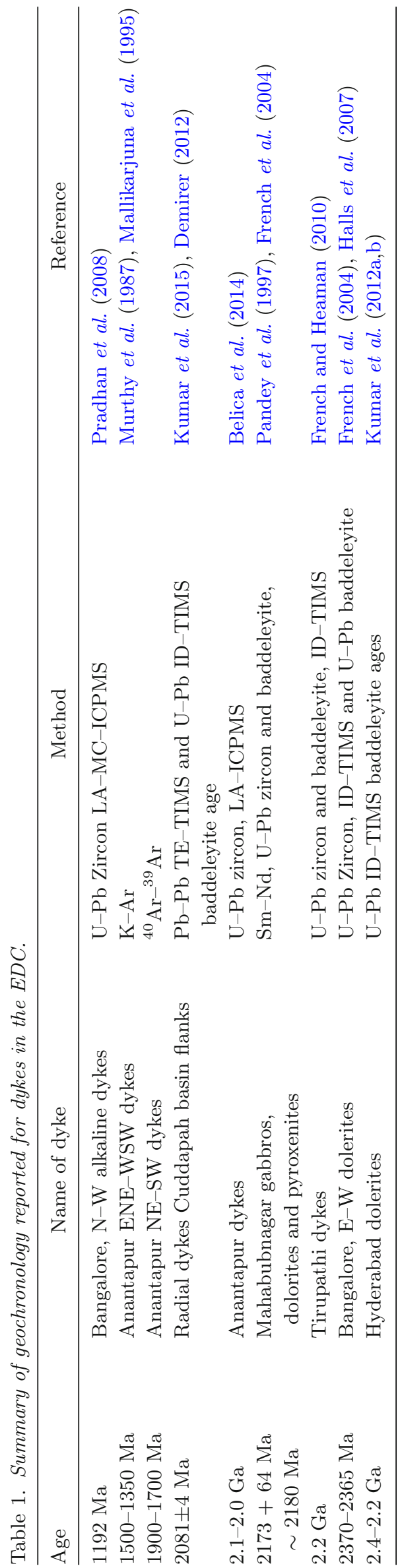

same rocks at $481 \pm 16 \mathrm{Ma}$ using a $\mathrm{Rb}-\mathrm{Sr}$ mineral isochron.

\subsubsection{Kandra ophiolite complex (KOC) and Kanigiri ophiolitic melange (KOM)}

The Kandra ophiolite complex is dated as around 1850-1900 Ma (SHRIMP U-Pb zircon ages by Vijaya Kumar et al. (2010) and Sm-Nd isochron age by Vadlamani (2010)). The Kanigiri complex is dated at around $1330 \mathrm{Ma}$ (LA-ICP-MS U-Pb zircon ages by Dharma Rao et al. 2011a). The timing of the post orogenic granite emplacement in the $\mathrm{KOM}$ is defined by the A-type Kanigiri granite intruding the KOM, dated at $1284 \mathrm{Ma}$ (Sain et al. 2017). There is a $500 \mathrm{My}$ age difference between these two ophiolite complexes and their history is proposed as an example of accretion along a craton margin over a prolonged period of convergence (Dharma Rao et al. 2011a). Saha (2011) proposed multiple cycles of ophiolite emplacement based on the divergent nature of thrusting in the area.

\subsubsection{Udaigiri Group and Prakasam alkaline complex}

The only age available from the Udaigiri Group is very poorly constrained at $1929 \pm 130$ Ma based on a single grain xenotime analysis by Das et al. (2015).

The Prakasam alkaline plutons occurring along the boundary between the Vinjamuru and Ongole domains are dated by various methods at between 1242 and $1369 \mathrm{Ma}$ (Upadhyay 2008 and references therein), interpreted to represent the rifting during the breakup of Columbia (Upadhyay 2008).

\subsection{Karimnagar and Bhopalpatnam granulite belts}

Santosh et al. (2004) report zircon (EPMA) ages from the KGB with the cores recording ages of up to $3.1 \mathrm{Ga}$ and rims with ages of $2.6 \mathrm{Ga}$. In contrast, the cores of zircons recovered from the BGB demonstrate core ages of $1.9 \mathrm{Ga}$ and the rims of 1.6-1.7 Ga. The monazites from the BGB also record the $1600 \pm 3 \mathrm{Ma}$ age, interpreted as the most important tectonothermal event in the BGB. As there are no Mesoproterozoic tectonothermal events recorded from the KGB, the KGB and $\mathrm{BGB}$ are interpreted to have experienced different $\mathrm{P}-\mathrm{T}$ conditions at different times (Santosh et al. 2004). The authors also note that the 1600 $\mathrm{Ma}$ age is not recorded from the KGB nor from 


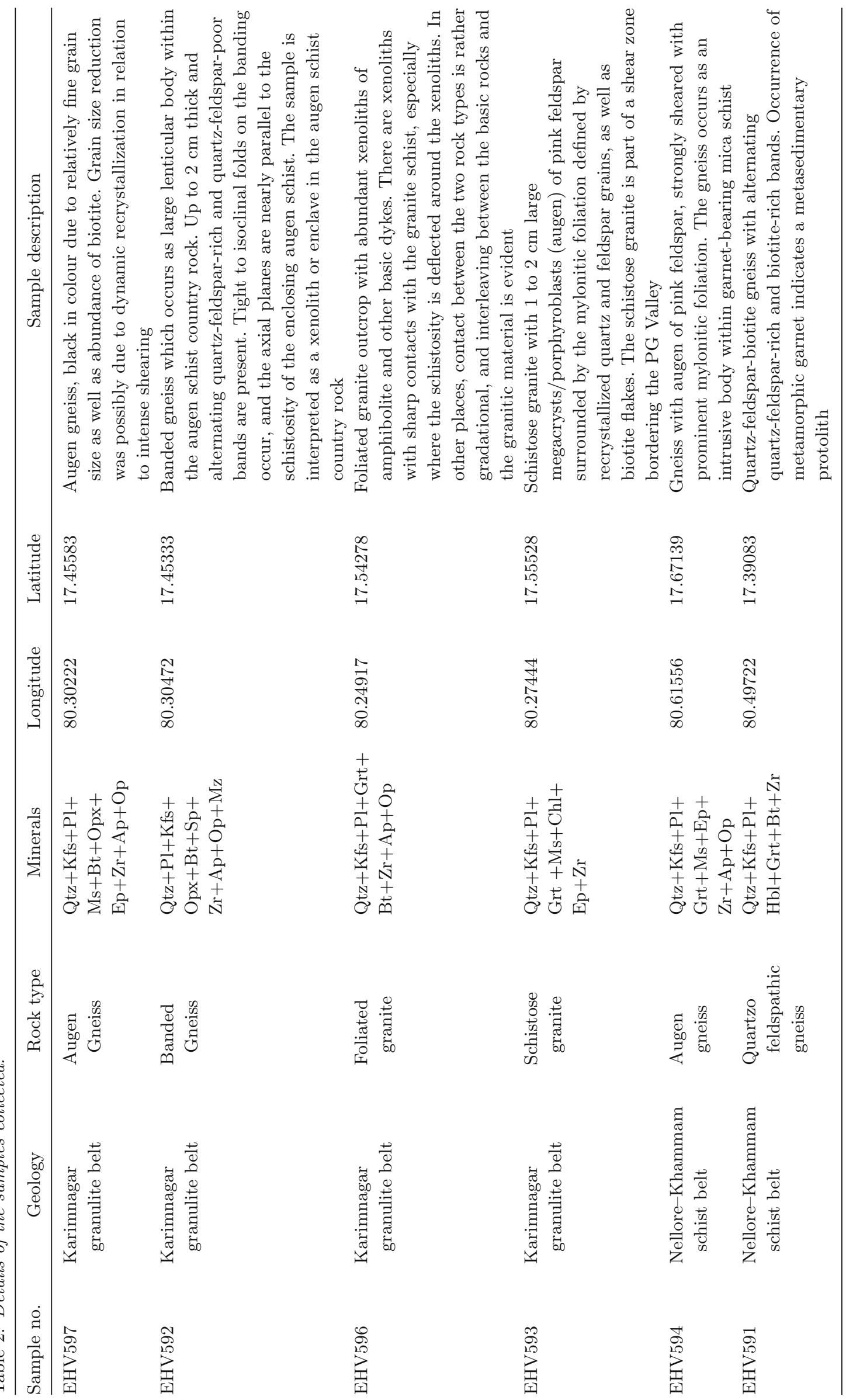




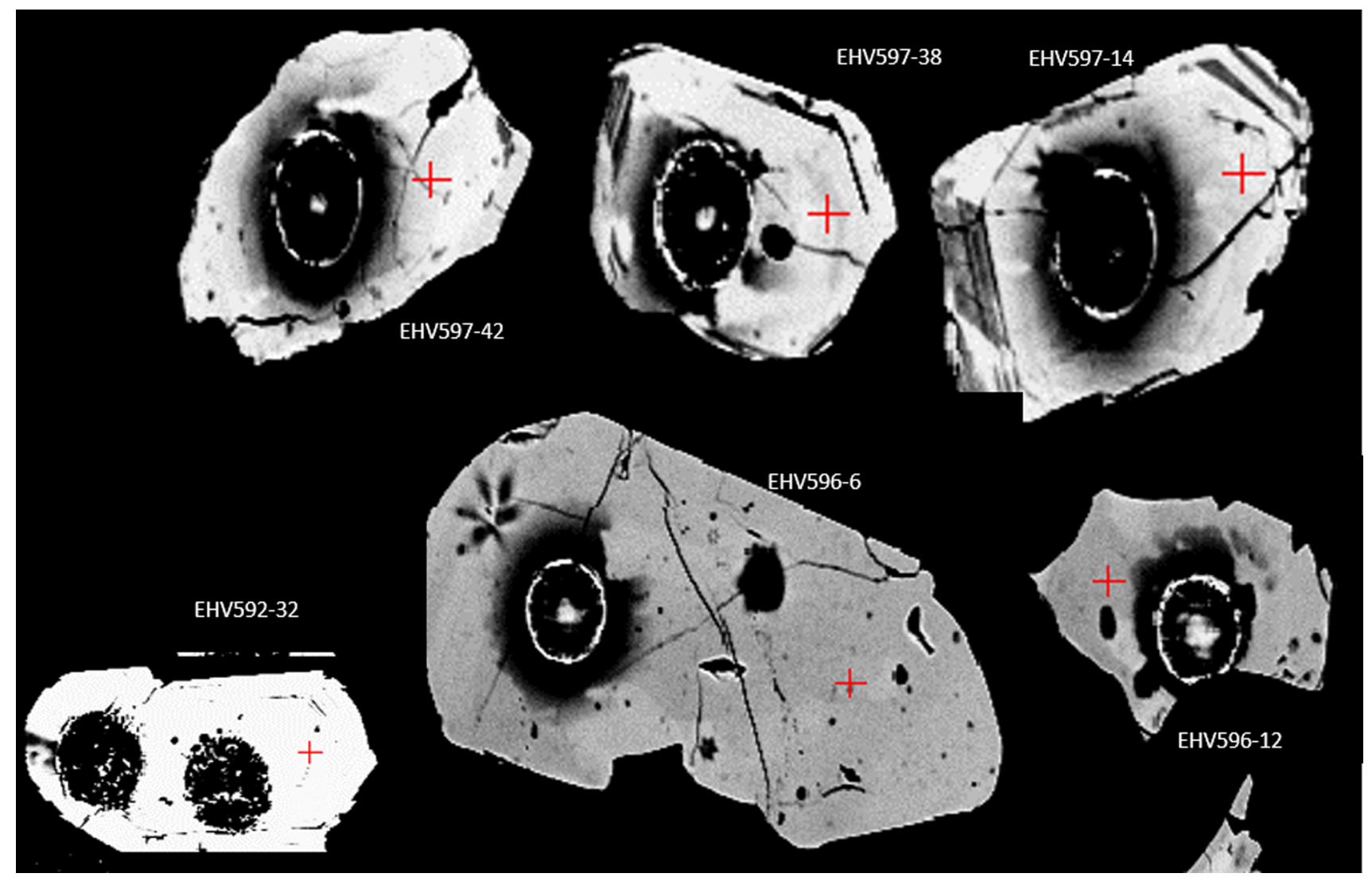

Figure 3. Examples of back scatter electron Z images captured using a CAMECA SX100 Electron Probe Micro Analyser for samples from the Karimnagar granulite belt. Ablation spots are $35 \mu \mathrm{m}$ in diameter and can be seen as circular holes.

the Bastar craton. Santosh et al. (2004) further note the absence of Grenvillian (ca. $1000 \mathrm{Ma}$ ) and Pan-African (ca. 520-550 Ma) ages from the KGB and suggest that the KGB was not directly involved in these younger collisional events that led to supercontinent amalgamation. The peak metamorphic age of the high $\mathrm{Mg}-\mathrm{Al}$ granulite in the KGB the area has been recently reported by Prakash et al. (2017) as 2604 \pm 25 Ma (SHRIMP $\mathrm{U}-\mathrm{Pb}$ zircon).

Granites intruding the supracrustal belt in the KGB are dated as $2490 \pm 115 \mathrm{Ma}$ ( $\mathrm{Rb}-\mathrm{Sr}$ whole rock; Crawford 1969). This event is probably linked to the rim ages reported by Santosh et al. (2004) in the zircons.

\subsection{Eastern Ghats mobile melt}

The Jaypore and Rengali provinces accreted to proto-India prior to the $1000 \mathrm{Ma}$ assembly of Rodinia (Mukhopadhyay and Basak 2009; Dasgupta et al. 2017). The EG province records high grade metamorphism and orogenesis at 980 $930 \mathrm{Ma}$ (SHRIMP U-Pb monazite dating) during amalgamation of Rodinia (Korhonen et al. 2011). The Ongole domain records collisional orogenesis and high temperature metamorphism at $1600 \mathrm{Ma}$ (Dobmeier and Raith 2003; Upadhyay et al. 2009; Henderson et al. 2013).

The crystallization of charnockites and enderbites in the centre of the Ongole domain is dated at 1720-1700 Ma (Kovach et al. 2001). The deposition of the sedimentary protolith in the Ongole domain is reported to be during $1.72-1.68 \mathrm{Ga}$ and based on the $\mathrm{U}-\mathrm{Pb}$ and $\mathrm{Lu}-\mathrm{Hf}$ data has been proposed not to be sourced from the Dharwar craton, but from the Napier Complex in Antarctica (Henderson et al. 2013). A small proportion of pre-Neoarchaean detrital zircons from the Ongole domain is also reported by Henderson et al. (2013). The granulite facies metamorphism in the Ongole domain is dated as 1.68-1.6 Ga (Henderson et al. 2013). It has been proposed that the Ongole domain accreted to proto-India during $1.68-1.6 \mathrm{Ga}$, as part of a linear accretionary orogenic belt (Henderson et al. 2013).

North of the Godavari Rift the granulite metamorphism and magnetism are mainly in the interval 


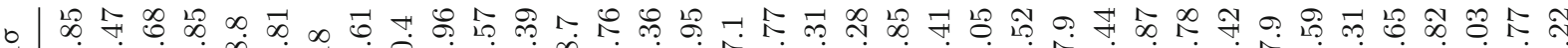

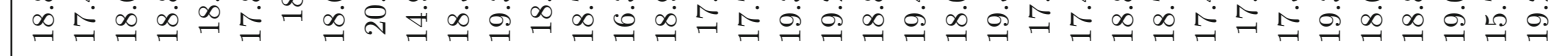
皮

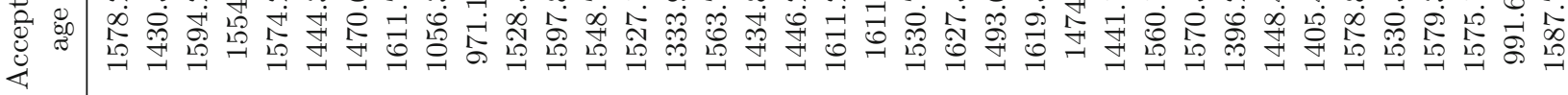

๖ 届

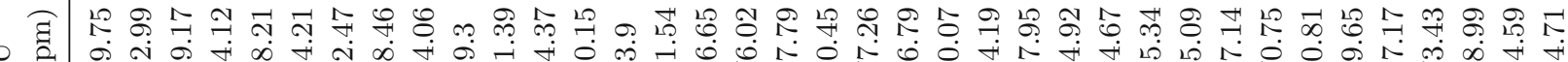

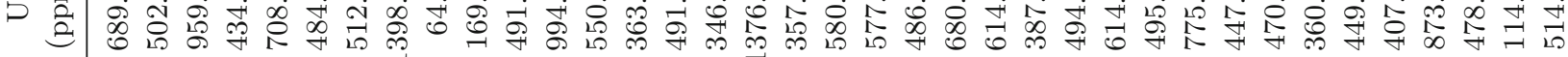

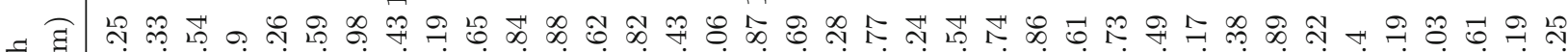

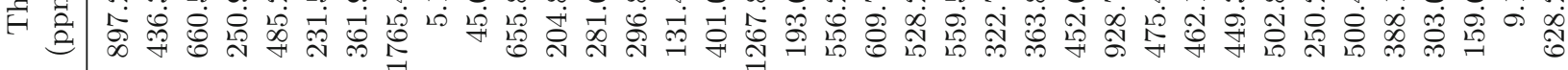

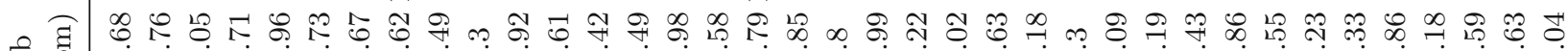

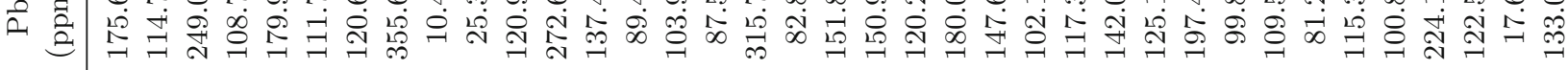

U m $0 m-4 n$ H मी

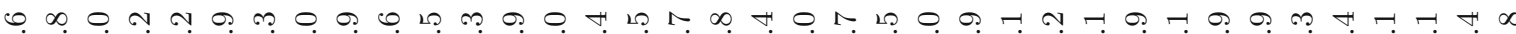
ลิ $\&$ ○

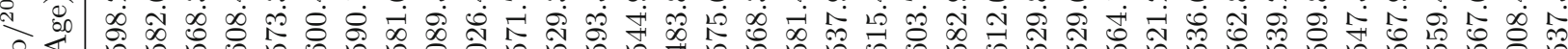
管

O.

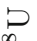
ㅎㅎㅇ \&

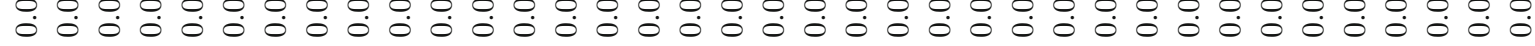

속

m 0 人

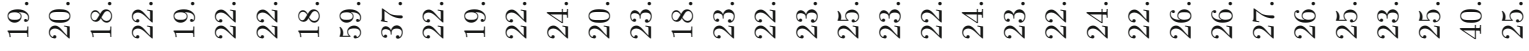

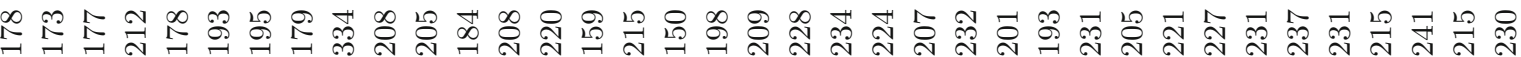

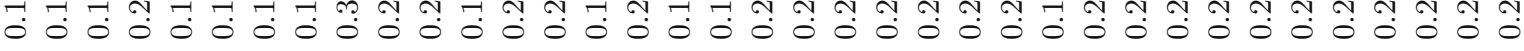

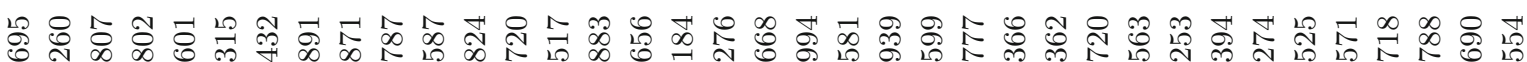

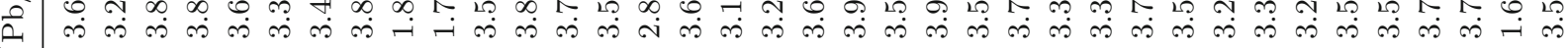

궁

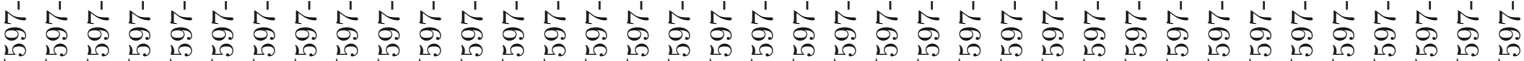

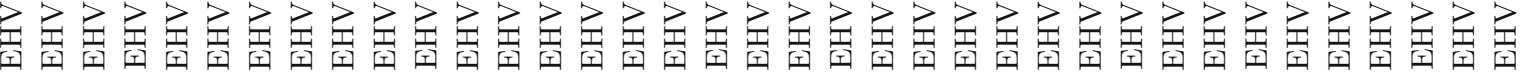




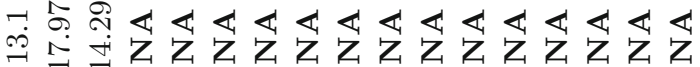

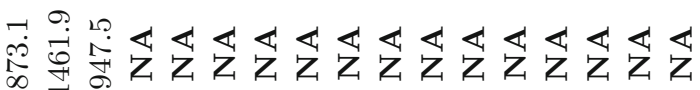

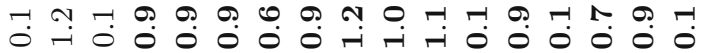

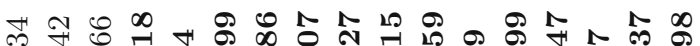

ஓं

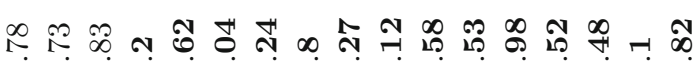
ㄱํㅇำ

궁ำ ㄱ

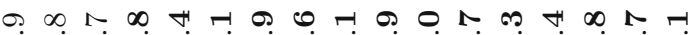
ヘ

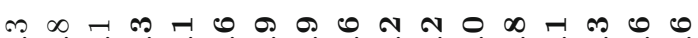

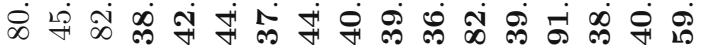

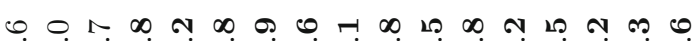
方

-0 -

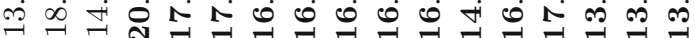

- 0 ฉ ヘ N ๓ ฉ

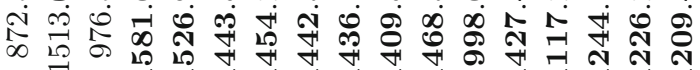

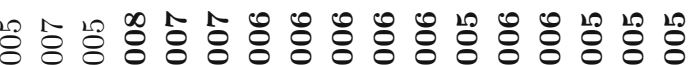

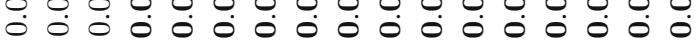

눈 2 人 Ұㄴำ

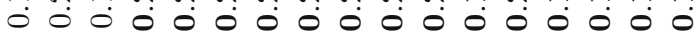

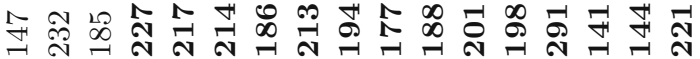

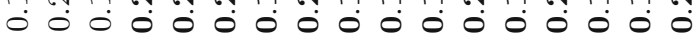

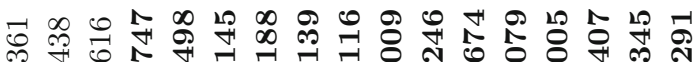
-

ำ

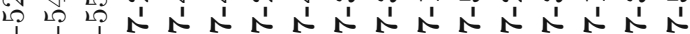

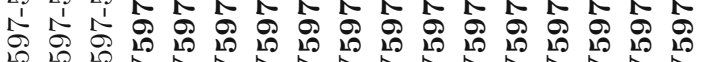

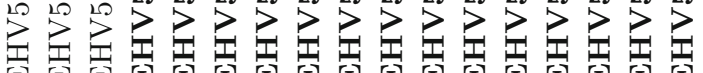

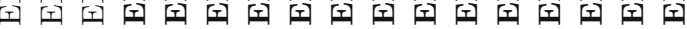

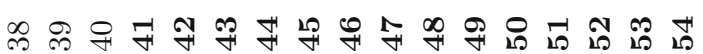

1.1-1.0 Ga and define the connection of EGMB with the Reyner-Napier complex of the Eastern Antarctica during the assembly of Rodinia (Rickers et al. 2001; Dobmeier and Raith 2003; Henderson et al. 2013; Dasgupta et al. 2017; Meert et al. 2017).

Saha et al. (2015) postulate long term episodic growth of the eastern craton margin of India in the Proterozoic, culminating in the final docking of the EGMB at $\sim 500 \mathrm{Ma}$ (also Biswal et al. 2007; Vijaya Kumar and Leelanandam 2008).

\section{Methodology}

\subsection{Sampling}

Samples $(\sim 5 \mathrm{~kg})$ of granite and gneiss were collected from the southeastern portion of the $\mathrm{P}-\mathrm{G}$ valley basin close to the boundary with the Eastern Ghats domain, which tectono-stratigraphically belongs to the Karimnagar granulite belt and the Khammam schist belt, i.e., the northern part of NKSB (table 2 and figure 2).

\subsection{Analytical method}

The samples were concentrated at the De Beers sample treatment centre, Bangalore, India. The treatment process consisted of crushing, screening, standard dense media separation (DMS), low intensity magnetic separation and heavy liquid separation through a lithium heteropolytungstate solution (LST). The resultant heavy mineral concentrate was partitioned to two size fractions, viz. $(+0.3-0.5 \mathrm{~mm})$ and $(+0.5-1.0 \mathrm{~mm})$. The zircons were identified visually under binocular microscopes and analysed at the De Beers Exploration Indicator Mineral Laboratory (DBE IML), Johannesburg. The handpicked zircons were mounted in $25 \mathrm{~mm}$ diameter epoxy mounts and polished to fully expose the midsection of the grains. Epoxy mount surfaces were cleaned using $96 \%$ ethanol and were put in a vacuum chamber to ensure sufficient outgassing of the epoxy.

The $\mathrm{U}-\mathrm{Pb}$ isotope analyses were done at the DBE IML, using a New Wave 193 Excimer laser ablation system equipped with a Large Format ablation cell and interfaced with a Thermo Fisher X-Series 2 quadrupole ICP-MS. The ICP-MS instrument was optimised for maximum sensitivity, stability and low background using the NIST610 glass standard. Ablations were carried out in a helium atmosphere, with a laser spot size of 
$35 \mu \mathrm{m}$. Ablation sites were placed at the centre of the zircon grains and away from cracks. Due to the small grain size, only one spot analysis was carried out per grain and it was not possible to carry out analyses of thin zircon rims. Unknowns and standards were ablated for $60 \mathrm{sec}$, followed by generous washouts of $5 \mathrm{~min}$. The masses ${ }^{206} \mathrm{~Pb}$, ${ }^{207} \mathrm{~Pb},{ }^{208} \mathrm{~Pb},{ }^{235} \mathrm{U},{ }^{238} \mathrm{U}$ and ${ }^{232} \mathrm{Th}$ were measured for $50 \mathrm{~ms}$ each, yielding a total sweep time of $300 \mathrm{~ms}$. Data reduction was done using the GLITTER Laser Ablation data reduction software (Van Achterbergh et al. 2001). The GJ-1 zircon standard (slightly discordant, ID-TIMS ${ }^{207} \mathrm{~Pb} /{ }^{206} \mathrm{~Pb}$ age $608.5 \pm 0.4 \mathrm{Ma}$, Jackson et al. 2004) was used as the calibration standard. Concordia diagrams and age calculations were performed using IsoPlot v. 3.70 (Ludwig 2001). BSE images of the analysed zircon grains (figures 3 and 5) were captured using a CAMECA SX100 Electron Probe Micro Analyser.

\section{Results}

\subsection{Samples from Karimnagar granulite belt}

EHV597 (Augen gneiss): A total of 54 zircons were recovered from the sample; these are euhedral to subhedral and are 150-250 $\mu \mathrm{m}$ in diameter (figure 3). Zircons are mostly unzoned with a few grains showing evidence of weak zonation (figure 3). Fourteen of the analyses are highly $(>10 \%)$ discordant (table 3). These highly discordant data are rejected and are not used for the interpretation (table 3 ). The obtained $\mathrm{U}-\mathrm{Pb}$ zircon age data form two concordant age groups. The dominant age group has a weighted average age of $1525 \pm 25 \mathrm{Ma}$ (MSWD 25). The average $\mathrm{Pb}$ and U concentrations (table 3 ) are 148 (81-355 ppm) and $598 \mathrm{ppm}$ (346-1398 ppm), respectively. The $\mathrm{Th} / \mathrm{U}$ ratio (table 3 ) average is $0.8(0.2-1.5)$. The second group (5 zircons) ranges in age between $873 \pm 13$ and $1056 \pm 20 \mathrm{Ma}$ and has a weighted average age of $953 \pm 79 \mathrm{Ma}$ with MSWD of 18 (figure 4). The average $\mathrm{Pb}$ and $\mathrm{U}$ concentrations (table 3 ) are 20 (10-25 ppm) and $136 \mathrm{ppm}$ (64$169 \mathrm{ppm}$ ), respectively. The $\mathrm{Th} / \mathrm{U}$ ratio (table 3 ) average is $0.14(0.1-0.3)$.

EHV592 (Banded gneiss): Zircons recovered are euhedral in shape and are 150-250 $\mu \mathrm{m}$ in diameter and are mostly unzoned (figure 3 ). A total of 42 zircons have been analysed. Unfortunately 19 grains produced highly discordant ( $>10 \%$ discordance) results (table 4), which are rejected and not used in the interpretation. Analysis of this sample presents a single age group (figure 4) with an intercept age of $1621 \pm 36 \mathrm{Ma}$ (MSWD 0.35). The average $\mathrm{Pb}$ and U concentrations (table 4$)$ are 76 (47-138 ppm) and 299 ppm (184-509 ppm), respectively. The Th/U ratio (table 4) average is $1.1(0.5-1.6)$.

EHV596 (Foliated granite): Zircon grains recovered from this sample are euhedral to subhedral, $150-250 \mu \mathrm{m}$ in diameter and in some grains there is evidence of zoning (figure 3). A total of 69 zircon grains have been recovered and analysed (table 5), of which four analysis have suspicious $\mathrm{U}, \mathrm{Pb}$ and $\mathrm{Th}$ concentrations, which have been removed (table 5), further removing of another 5 apparently inherited zircons, result in an intercept age of $2428 \pm 16 \mathrm{Ma}$ (figure 4). This is interpreted as the intrusion age of the granite. The average $\mathrm{Pb}$ and $\mathrm{U}$ concentrations (table 5) are 49 (15-197 $\mathrm{ppm})$ and $113 \mathrm{ppm}(35-454 \mathrm{ppm})$, respectively. The $\mathrm{Th} / \mathrm{U}$ ratio (table 5) average is $1.0(0.5-2.4)$.

EHV593 (Schistose granite): Zircons are similar to those recovered from EHV596. A total of 30 grains have been analysed, of which 9 have high discordance and were removed (table 6). The U-Pb isotope system appears to be disturbed and did not result in an interpreted concordia age for this sample. Weighted average of the accepted single system ages (figure 4) result in $2480 \pm 31 \mathrm{Ma}$ (MSWD 6.0). This is interpreted as the age of the granite with low confidence. The average $\mathrm{Pb}$ and $\mathrm{U}$ concentrations are 124 (45-522 ppm) and $288 \mathrm{ppm}$ (106-1253 ppm), respectively. The $\mathrm{Th} / \mathrm{U}$ ratio (table 6 ) average is $0.9(0.2-2.0)$.

\subsection{Samples from Khammam schist belt}

EHV594 (Augen gneiss): Zircons recovered are euhedral to subhedral, are 150-250 $\mu \mathrm{m}$ in diameter and demonstrate some evidence of zoning (figure 5). A total of 43 zircon grains were recovered and analysed out of which 12 analyses are highly discordant ( $>10 \%$; table 7$)$ and are not used in the interpretation.

There are four different age groups evident from the data (figure 6 and table 7). Age group 1 is represented by two grains only with very concordant analyses. A weighted average age of $3212 \pm 36$ Ma (MSWD 0.102) is obtained for the two grains. The average $\mathrm{Pb}$ and $\mathrm{U}$ concentrations (table 7 ) are 154 (151-158) and $258 \mathrm{ppm}$ (244-271 ppm), respectively. The $\mathrm{Th} / \mathrm{U}$ ratio (table 7 ) average is 

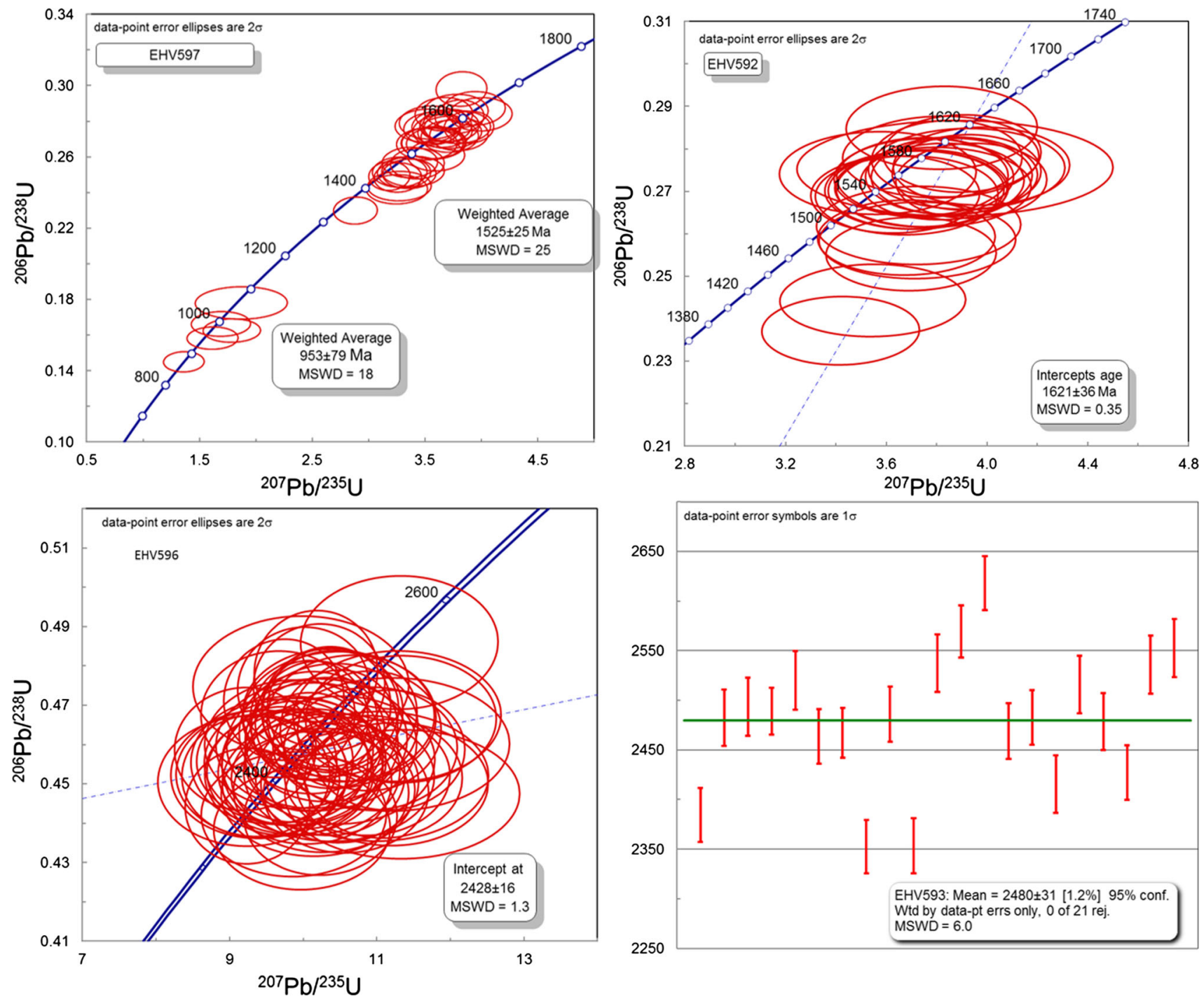

Figure 4. U-Pb concordia diagram of zircons from the Karimnagar granulites and the granites. EHV593 is the weighted average of accepted single system ages.

0.5 (0.4-0.5). Age group 2 has seven concordant data points and is represented with weighted average age of $2587 \pm 130 \mathrm{Ma}$ (MSWD 23). The average $\mathrm{Pb}$ and $\mathrm{U}$ concentrations (table 7 ) for this group are 74 (44-103 ppm) and $164 \mathrm{ppm}(81-217 \mathrm{ppm})$, respectively. The $\mathrm{Th} / \mathrm{U}$ ratio (table 7 ) average is 0.9 (0.5-1.4). Age group 3 is the most prominent and is represented by 21 analyses of low discordance $(<10 \%)$. This age group is represented with weighted average age of $1807 \pm 37 \mathrm{Ma}$ (figure 6). The average $\mathrm{Pb}$ and $\mathrm{U}$ concentrations (table 7 ) for this group are 131 (32-405 ppm) and $454 \mathrm{ppm}$ (115-1472 ppm), respectively with the Th/U ratio (table 7 ) average of $0.6(0.2-1.9)$. The 4 th group is represented by a single concordant zircon grain with an age of $522 \pm 25$ Ma (figure 6 and table 7 ). The $\mathrm{Pb}$ and $\mathrm{U}$ concentrations for this zircon is 37 and $484 \mathrm{ppm}$, respectively with the $\mathrm{Th} / \mathrm{U}$ ratio of 0.3 (table 7).

EHV591 (Quartzo-feldspathic gneiss): Zircons recovered are euhedral to subhedral and are 150$250 \mu \mathrm{m}$ in diameter (figure 5). Zircons demonstrate stronger zonation than the samples from the KGB (figure 5). A total of 57 zircons were recovered and analysed, with eight analyses of high discordance (table 8 and figure 6 ). There are three different concordant age groups evident from the data (figure 6 and table 7 ).

Age group 1 is represented by three grains with $<10 \%$ discordance and with a weighted average age of $3043 \pm 230 \mathrm{Ma}$. The average $\mathrm{Pb}$ and $\mathrm{U}$ concentrations (table 8) for this group are 50 (7-129 ppm) and $127 \mathrm{ppm}$ (77-226 ppm), respectively with the $\mathrm{Th} / \mathrm{U}$ ratio (table 8 ) average of $0.4(0.4-0.5)$. Age 


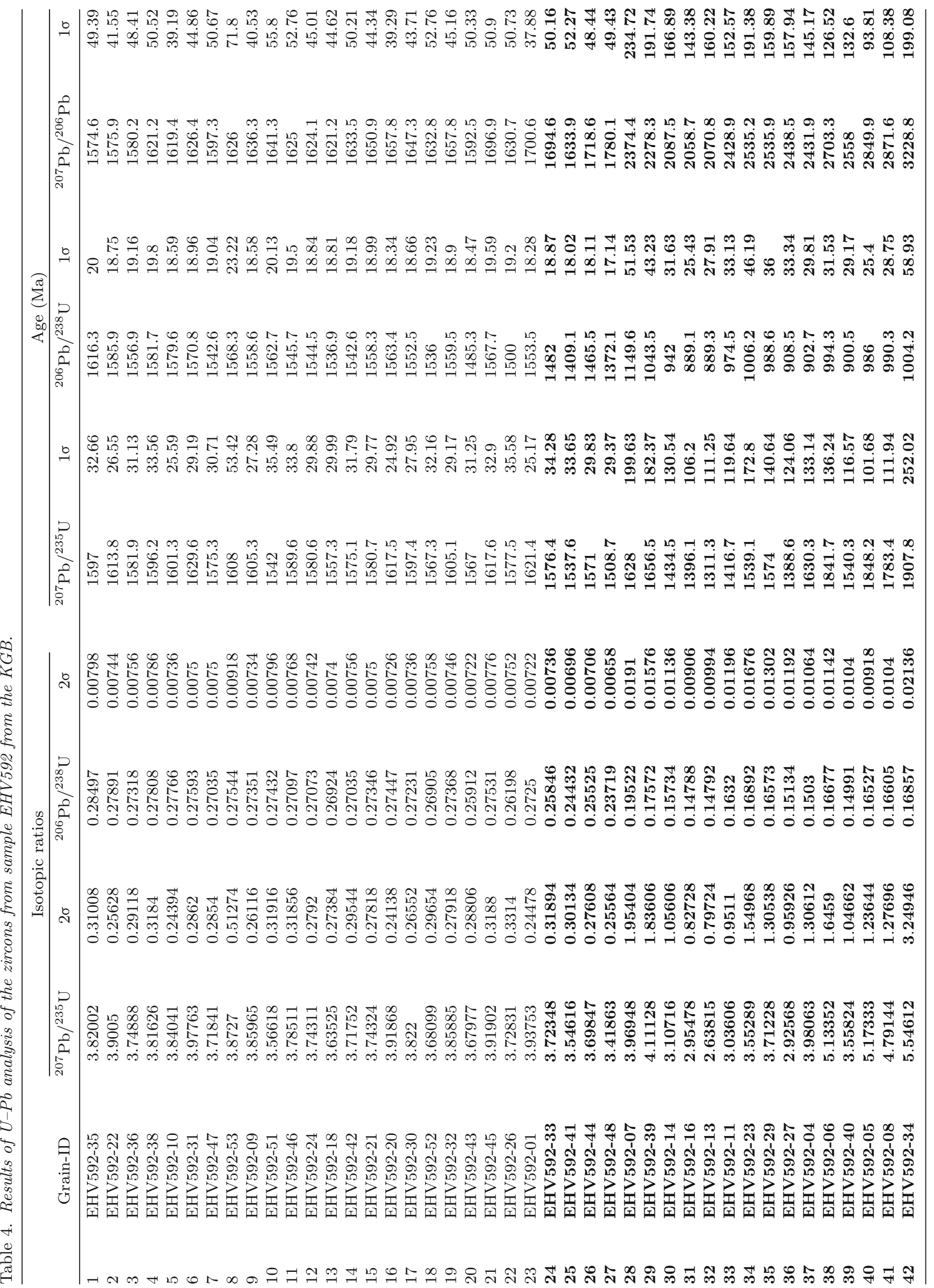


Table 4. (Continued.)

\begin{tabular}{|c|c|c|c|c|c|c|c|}
\hline & $\begin{array}{l}\text { Disc } \\
(\%)\end{array}$ & $\begin{array}{c}\mathrm{Pb} \\
(\mathrm{ppm})\end{array}$ & $\begin{array}{c}\mathrm{Th} \\
(\mathrm{ppm})\end{array}$ & $\begin{array}{c}\mathrm{U} \\
(\mathrm{ppm})\end{array}$ & $\mathrm{Th} / \mathrm{U}$ & $\begin{array}{l}\text { Accepted } \\
\text { age }(\mathrm{Ma})\end{array}$ & $1 \sigma$ \\
\hline 1 & -2.6 & 57.1 & 217.35 & 215.01 & 1.0 & 1616.3 & 20 \\
\hline 2 & -0.6 & 92.82 & 187.02 & 358.83 & 0.5 & 1585.9 & 18.75 \\
\hline 3 & 1.5 & 62.85 & 280.87 & 246.79 & 1.1 & 1556.9 & 19.16 \\
\hline 4 & 2.4 & 58.98 & 211.34 & 226.44 & 0.9 & 1581.7 & 19.8 \\
\hline 5 & 2.5 & 130.65 & 732.72 & 509.89 & 1.4 & 1579.6 & 18.59 \\
\hline 6 & 3.4 & 79.37 & 223.55 & 309.1 & 0.7 & 1570.8 & 18.96 \\
\hline 7 & 3.4 & 89.76 & 288.2 & 353.4 & 0.8 & 1542.6 & 19.04 \\
\hline 8 & 3.5 & 63.59 & 377.86 & 249.37 & 1.5 & 1568.3 & 23.22 \\
\hline 9 & 4.7 & 71.31 & 248.32 & 282.65 & 0.9 & 1558.6 & 18.58 \\
\hline 10 & 4.8 & 47.48 & 196.65 & 184.64 & 1.1 & 1562.7 & 20.13 \\
\hline 11 & 4.9 & 70.8 & 214.54 & 275.19 & 0.8 & 1545.7 & 19.5 \\
\hline 12 & 4.9 & 58.63 & 359.22 & 233.34 & 1.5 & 1544.5 & 18.84 \\
\hline 13 & 5.2 & 59.18 & 171.13 & 235.07 & 0.7 & 1536.9 & 18.81 \\
\hline 14 & 5.6 & 61.3 & 243.07 & 242.6 & 1.0 & 1542.6 & 19.18 \\
\hline 15 & 5.6 & 61.46 & 314.02 & 242.44 & 1.3 & 1558.3 & 18.99 \\
\hline 16 & 5.7 & 114.87 & 342.12 & 451.8 & 0.8 & 1563.4 & 18.34 \\
\hline 17 & 5.8 & 95.32 & 307.12 & 376.45 & 0.8 & 1552.5 & 18.66 \\
\hline 18 & 5.9 & 79.22 & 340.94 & 313.98 & 1.1 & 1536 & 19.23 \\
\hline 19 & 5.9 & 75.81 & 470.83 & 297.56 & 1.6 & 1559.5 & 18.9 \\
\hline 20 & 6.7 & 92.32 & 605.92 & 381.02 & 1.6 & 1485.3 & 18.47 \\
\hline 21 & 7.6 & 72.06 & 337.81 & 279.73 & 1.2 & 1567.7 & 19.59 \\
\hline 22 & 8.0 & 61.79 & 244.88 & 248.87 & 1.0 & 1500 & 19.2 \\
\hline 23 & 8.6 & 92.33 & 395.11 & 368.18 & 1.1 & 1553.5 & 18.28 \\
\hline 24 & 12.5 & 84.83 & 259.55 & 339.01 & 0.8 & NA & NA \\
\hline 25 & 13.8 & 111.96 & 804.59 & 458.45 & 1.8 & NA & NA \\
\hline 26 & 14.7 & 88.75 & 453.23 & 371.74 & 1.2 & NA & NA \\
\hline 27 & 22.9 & 99.41 & 455.19 & 450.24 & 1.0 & NA & NA \\
\hline 28 & 51.6 & 1.326 & 18.96 & 7.37 & 2.6 & NA & NA \\
\hline 29 & 54.2 & 1.282 & 10.27 & 7.63 & 1.3 & NA & NA \\
\hline 30 & 54.9 & 1.588 & 9.96 & 10.84 & 0.9 & NA & NA \\
\hline 31 & 56.8 & 1.78 & 12.02 & 12.37 & 1.0 & NA & NA \\
\hline 32 & 57.1 & 1.69 & 12.53 & 12.33 & 1.0 & NA & NA \\
\hline 33 & 59.9 & 1.72 & 17.76 & 11.42 & 1.6 & NA & NA \\
\hline 34 & 60.3 & 0.708 & 1.81 & 4.52 & 0.4 & NA & NA \\
\hline 35 & 61.0 & 1.274 & 13.31 & 8.27 & 1.6 & NA & NA \\
\hline 36 & 62.7 & 1.427 & 15.51 & 10.15 & 1.5 & NA & NA \\
\hline 37 & 62.9 & 1.499 & 10.7 & 10.84 & 1.0 & NA & NA \\
\hline 38 & 63.2 & 1.98 & 30.06 & 12.91 & 2.3 & NA & NA \\
\hline 39 & 64.8 & 1.41 & 8.47 & 10.17 & 0.8 & NA & NA \\
\hline 40 & 65.4 & 147.69 & 8359.72 & 970.32 & 8.6 & NA & NA \\
\hline 41 & 65.5 & 77.27 & 4763.23 & 504.64 & 9.4 & NA & NA \\
\hline 42 & 68.9 & 0.555 & 8.28 & 3.53 & 2.3 & NA & NA \\
\hline
\end{tabular}

NA: Not Applicable. Bold data are rejected and not utilised in the analysis. Discordance is defined as 1$\left({ }^{206} \mathrm{~Pb} /{ }^{238} \mathrm{U}\right.$ Age $\div{ }^{207} \mathrm{~Pb} /{ }^{206} \mathrm{~Pb}$ Age $)$.

group 2 is most prominent with 45 data points, five of which are highly discordant $(>10 \%)$ and are not used in the interpretation (table 8 and figure 6). This age group ranges between $2005 \pm 28$ and $2541 \pm 29 \mathrm{Ma}$ and with a weighted average age of $2396 \pm 24 \mathrm{Ma}$. The average $\mathrm{Pb}$ and $\mathrm{U}$ concentrations (table 8) for this group are 104 (6-441 ppm) and 279 (19-1034 ppm), respectively with the $\mathrm{Th} / \mathrm{U}$ ratio (table 8$)$ average of $1.2(0.1-2.7)$. The third age group is represented by a single zircon grain giving an age of $472 \pm 9 \mathrm{Ma}$ (figure 6 and table 8). The $\mathrm{Pb}$ and $\mathrm{U}$ concentrations for this zircon is 200 and $82 \mathrm{ppm}$, respectively with the $\mathrm{Th} / \mathrm{U}$ ratio of 1.8 (table 8).

\section{Discussion}

Unravelling of overprinting multiple tectonothermal events by the in-situ $\mathrm{U}-\mathrm{Pb}$ geochronology in 


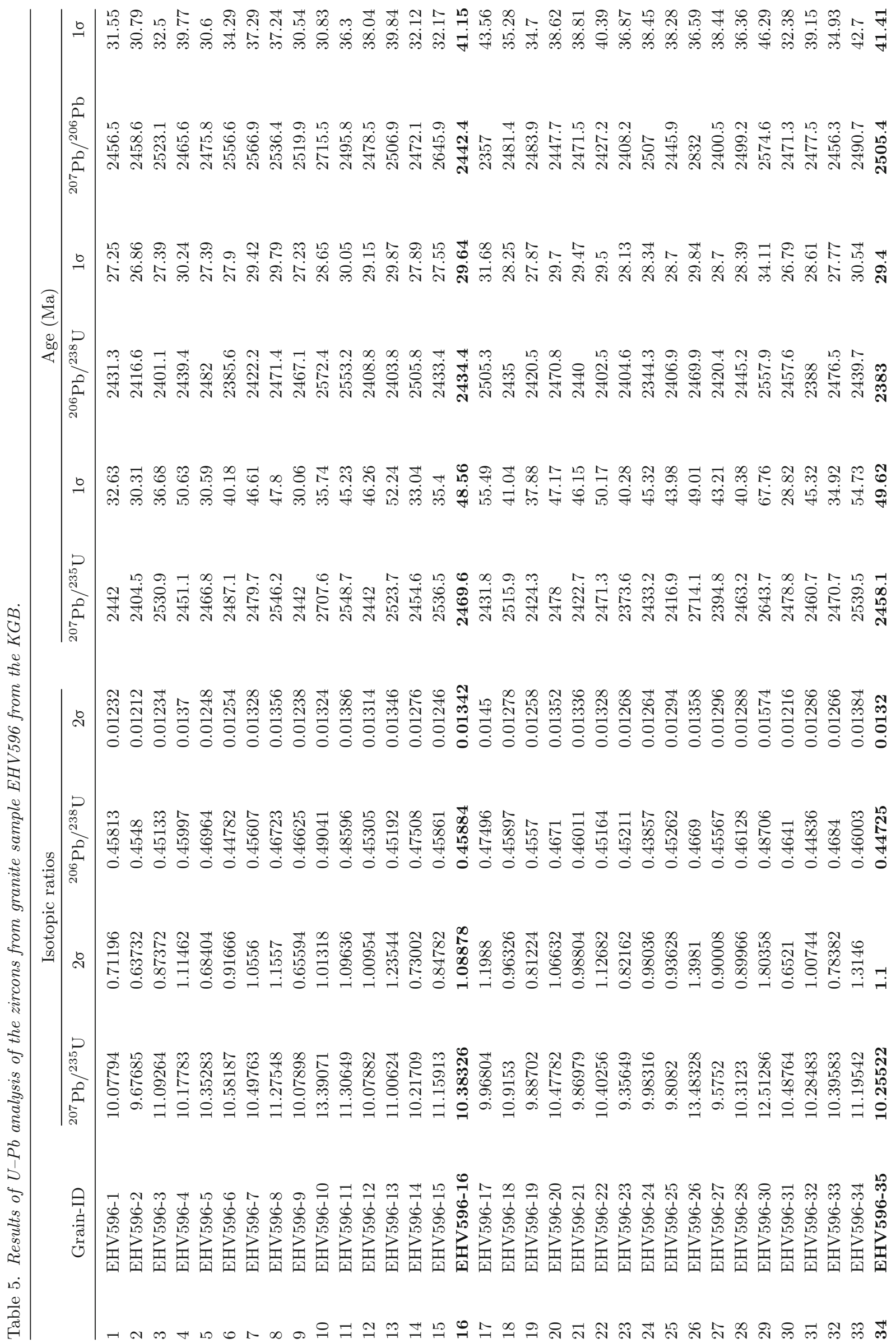




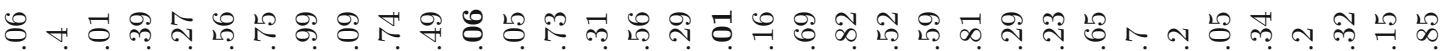

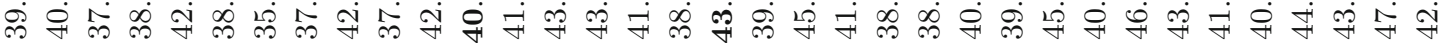

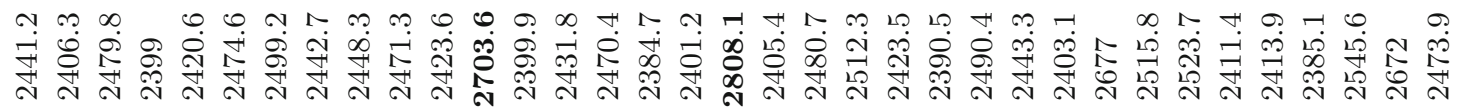

유

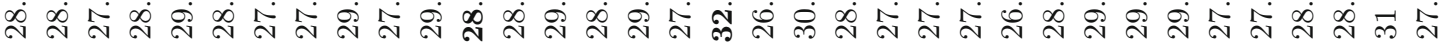

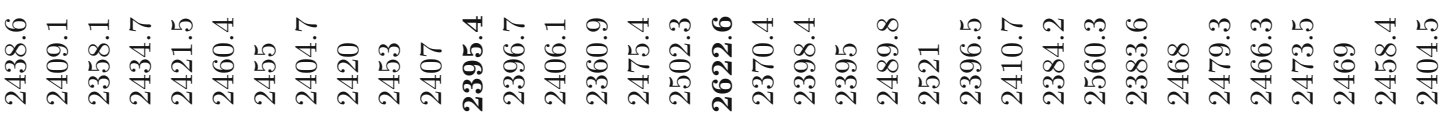

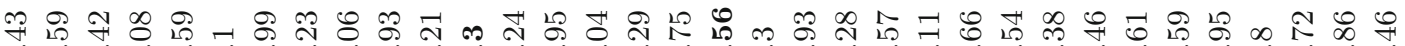

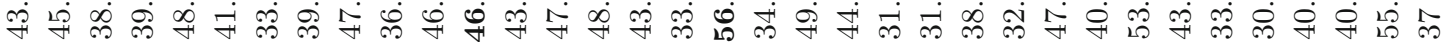

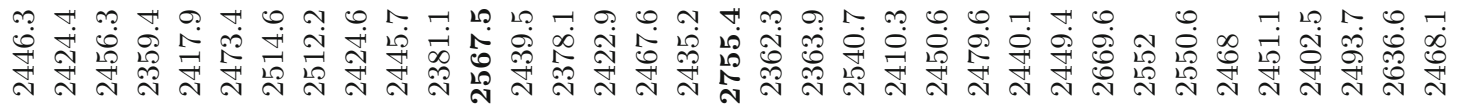

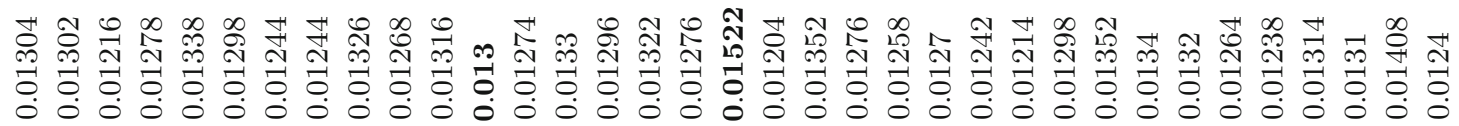

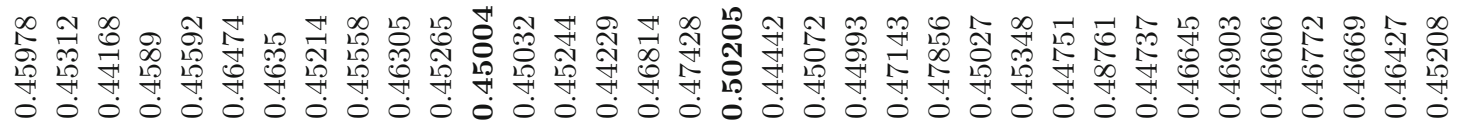

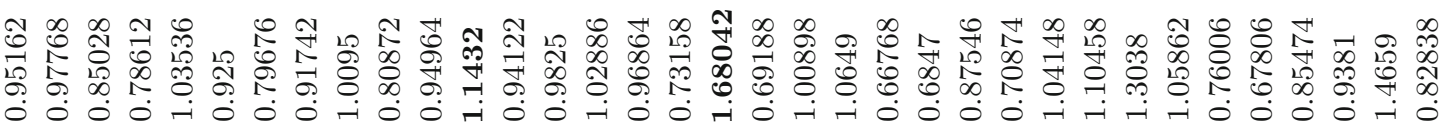

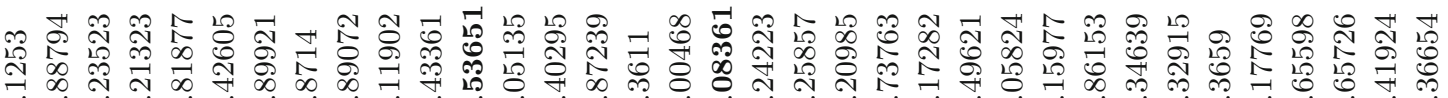

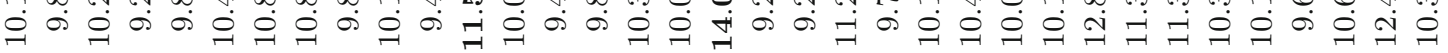

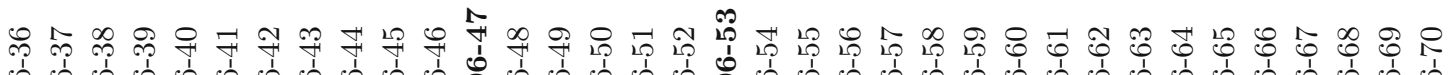
至

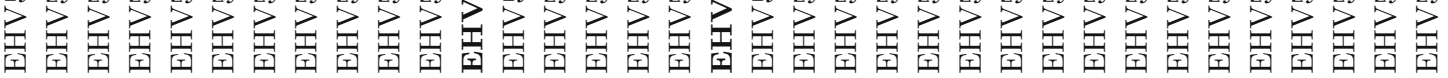


Table 5. (Continued.)

\begin{tabular}{|c|c|c|c|c|c|c|c|}
\hline & $\begin{array}{c}\text { Disc } \\
(\%)\end{array}$ & $\begin{array}{c}\mathrm{Pb} \\
(\mathrm{ppm})\end{array}$ & $\begin{array}{c}\text { Th } \\
(\mathrm{ppm})\end{array}$ & $\begin{array}{c}\mathrm{U} \\
(\mathrm{ppm})\end{array}$ & $\mathrm{Th} / \mathrm{U}$ & $\begin{array}{l}\text { Accepted } \\
\text { age }(\mathrm{Ma})\end{array}$ & $1 \sigma$ \\
\hline 1 & 1.0 & 58.29 & 121.39 & 136.22 & 0.9 & 2431.3 & 27.25 \\
\hline 2 & 1.7 & 68.07 & 158.84 & 160.24 & 1.0 & 2416.6 & 26.86 \\
\hline 3 & 4.8 & 43.62 & 78.24 & 103.48 & 0.8 & 2401.1 & 27.39 \\
\hline 4 & 1.1 & 32.4 & 75.62 & 75.41 & 1.0 & 2439.4 & 30.24 \\
\hline 5 & -0.3 & 65.54 & 131.4 & 149.43 & 0.9 & 2482 & 27.39 \\
\hline 6 & 6.7 & 34.09 & 94.25 & 81.52 & 1.2 & 2385.6 & 27.9 \\
\hline 7 & 5.6 & 22.45 & 38.76 & 52.71 & 0.7 & 2422.2 & 29.42 \\
\hline 8 & 2.6 & 22.9 & 59.89 & 52.49 & 1.1 & 2471.4 & 29.79 \\
\hline 9 & 2.1 & 71.46 & 102.98 & 164.16 & 0.6 & 2467.1 & 27.23 \\
\hline 10 & 5.3 & 83.96 & 178.39 & 183.38 & 1.0 & 2572.4 & 28.65 \\
\hline 11 & -2.3 & 56.14 & 136.84 & 123.76 & 1.1 & 2553.2 & 30.05 \\
\hline 12 & 2.8 & 23.54 & 48.48 & 55.66 & 0.9 & 2408.8 & 29.15 \\
\hline 13 & 4.1 & 17.71 & 35.38 & 43.53 & 0.8 & 2403.8 & 29.87 \\
\hline 14 & -1.4 & 34.72 & 38.6 & 80.9 & 0.5 & 2505.8 & 27.89 \\
\hline 15 & 8.0 & 51.89 & 291.88 & 121.23 & 2.4 & 2433.4 & 27.55 \\
\hline 16 & 0.3 & 1.56 & NA & 1.03 & NA & 2434.4 & 29.64 \\
\hline 17 & -6.3 & 15.57 & 31.66 & 35.23 & 0.9 & 2505.3 & 31.68 \\
\hline 18 & 1.9 & 37.8 & 92.33 & 88.28 & 1.0 & 2435 & 28.25 \\
\hline 19 & 2.6 & 37.53 & 93.6 & 88.27 & 1.1 & 2420.5 & 27.87 \\
\hline 20 & -0.9 & 33.79 & 42.77 & 77.53 & 0.6 & 2470.8 & 29.7 \\
\hline 21 & 1.3 & 25.84 & 67.88 & 60.2 & 1.1 & 2440 & 29.47 \\
\hline 22 & 1.0 & 21.24 & 33.12 & 50.41 & 0.7 & 2402.5 & 29.5 \\
\hline 23 & 0.1 & 33.34 & 80.11 & 79.06 & 1.0 & 2404.6 & 28.13 \\
\hline 24 & 6.5 & 24.61 & 44.41 & 60.16 & 0.7 & 2344.3 & 28.34 \\
\hline 25 & 1.6 & 25.94 & 50.95 & 61.45 & 0.8 & 2406.9 & 28.7 \\
\hline 26 & 12.8 & 19.75 & 44.89 & 45.09 & 1.0 & NA & NA \\
\hline 27 & -0.8 & 29.4 & 66.09 & 69.19 & 1.0 & 2420.4 & 28.7 \\
\hline 28 & 2.2 & 35.16 & 80.18 & 81.75 & 1.0 & 2445.2 & 28.39 \\
\hline 29 & 0.6 & 23.82 & 42.13 & 52.46 & 0.8 & 2557.9 & 34.11 \\
\hline 30 & 0.6 & 114.09 & 281.96 & 263.72 & 1.1 & 2457.6 & 26.79 \\
\hline 31 & 3.6 & 27.6 & 52.53 & 66.05 & 0.8 & 2388 & 28.61 \\
\hline 32 & -0.8 & 85.78 & 289.97 & 196.51 & 1.5 & 2476.5 & 27.77 \\
\hline 33 & 2.0 & 16.38 & 37.42 & 36.58 & 1.0 & 2439.7 & 30.54 \\
\hline 34 & 4.9 & NA & NA & NA & NA & 2383 & 29.4 \\
\hline 35 & 0.1 & 31.62 & 77.05 & 73.81 & 1.0 & 2438.6 & 28.79 \\
\hline 36 & -0.1 & 27.39 & 60.36 & 64.88 & 0.9 & 2409.1 & 28.86 \\
\hline 37 & 4.9 & 42.12 & 76.67 & 102.35 & 0.7 & 2358.1 & 27.21 \\
\hline 38 & -1.5 & 40.64 & 144.45 & 95.05 & 1.5 & 2434.7 & 28.23 \\
\hline 39 & 0.0 & 23.33 & 57.02 & 54.94 & 1.0 & 2421.5 & 29.61 \\
\hline 40 & 0.6 & 44.7 & 73.87 & 103.28 & 0.7 & 2460.4 & 28.58 \\
\hline 41 & 1.8 & 73.81 & 163.21 & 170.98 & 1.0 & 2455 & 27.4 \\
\hline 42 & 1.6 & 51.39 & 141.41 & 122.05 & 1.2 & 2404.7 & 27.61 \\
\hline 43 & 1.2 & 28.16 & 82.3 & 66.38 & 1.2 & 2420 & 29.34 \\
\hline 44 & 0.7 & 53.86 & 93.98 & 124.93 & 0.8 & 2453 & 27.92 \\
\hline 45 & 0.7 & 26.57 & 69.13 & 63.05 & 1.1 & 2407 & 29.18 \\
\hline 46 & 11.4 & 49.91 & 98.73 & 119.12 & 0.8 & NA & NA \\
\hline 47 & 0.1 & 33.57 & 156.5 & 80.09 & 2.0 & 2396.7 & 28.31 \\
\hline 48 & 1.1 & 23.26 & 50.97 & 55.24 & 0.9 & 2406.1 & 29.53 \\
\hline 49 & 4.4 & 26.44 & 108.33 & 64.23 & 1.7 & 2360.9 & 28.96 \\
\hline 50 & -3.8 & 38.87 & 62.48 & 89.22 & 0.7 & 2475.4 & 29.01 \\
\hline 51 & -4.2 & 81.56 & 171.85 & 184.8 & 0.9 & 2502.3 & 27.89 \\
\hline 52 & 6.6 & NA & NA & 0.84 & NA & 2622.6 & 32.65 \\
\hline
\end{tabular}


Table 5. (Continued.)

\begin{tabular}{|c|c|c|c|c|c|c|c|}
\hline & $\begin{array}{l}\text { Disc } \\
(\%)\end{array}$ & $\begin{array}{c}\mathrm{Pb} \\
(\mathrm{ppm})\end{array}$ & $\begin{array}{c}\text { Th } \\
(\mathrm{ppm})\end{array}$ & $\begin{array}{c}\mathrm{U} \\
(\mathrm{ppm})\end{array}$ & $\mathrm{Th} / \mathrm{U}$ & $\begin{array}{l}\text { Accepted } \\
\text { age }(\mathrm{Ma})\end{array}$ & $1 \sigma$ \\
\hline 53 & 1.5 & 70.05 & 147.58 & 169.43 & 0.9 & 2370.4 & 26.86 \\
\hline 54 & 3.3 & 18.63 & 70.99 & 40.72 & 1.7 & 2398.4 & 30.03 \\
\hline 55 & 4.7 & 33.96 & 85.05 & 81.13 & 1.0 & 2395 & 28.35 \\
\hline 56 & -2.7 & 113.04 & 318.76 & 257.81 & 1.2 & 2489.8 & 27.54 \\
\hline 57 & -5.5 & 132.3 & 210.98 & 297.26 & 0.7 & 2521 & 27.7 \\
\hline 58 & 3.8 & 48.53 & 141.06 & 115.89 & 1.2 & 2396.5 & 27.62 \\
\hline 59 & 1.3 & 105.52 & 255.92 & 250.24 & 1.0 & 2410.7 & 26.93 \\
\hline 60 & 0.8 & 30.37 & 91.22 & 72.99 & 1.2 & 2384.2 & 28.91 \\
\hline 61 & 4.4 & 55.82 & 117.92 & 123.13 & 1.0 & 2560.3 & 29.29 \\
\hline 62 & 5.3 & 23.43 & 55.42 & 56.34 & 1.0 & 2383.6 & 29.83 \\
\hline 63 & 2.2 & 53.55 & 114.77 & 123.5 & 0.9 & 2468 & 29.01 \\
\hline 64 & -2.8 & 125.02 & 375.46 & 286.81 & 1.3 & 2479.3 & 27.74 \\
\hline 65 & -2.2 & 196.87 & 612.01 & 454.54 & 1.3 & 2466.3 & 27.23 \\
\hline 66 & -3.7 & 47.66 & 94.31 & 109.67 & 0.9 & 2473.5 & 28.84 \\
\hline 67 & 3.0 & 49.03 & 65.94 & 113.08 & 0.6 & 2469 & 28.77 \\
\hline 68 & 8.0 & 20.3 & 47.05 & 41.72 & 1.1 & 2458.4 & 31 \\
\hline 69 & 2.8 & 123.13 & 360.46 & 293.18 & 1.2 & 2404.5 & 27.54 \\
\hline
\end{tabular}

NA: Not applicable. Bold data are rejected and not utilised in the analysis. Discordance is defined as $1-\left({ }^{206} \mathrm{~Pb} /{ }^{238} \mathrm{U}\right.$ Age $\div{ }^{207} \mathrm{~Pb} /{ }^{206} \mathrm{~Pb}$ Age) .

single samples have been reported earlier (Wang et al. 2007; Zhang et al. 2008; Ma et al. 2012), based on resetting of the $\mathrm{U}-\mathrm{Pb}$ system in pre-existing zircons due to tectonothermal effects or multiple recrystallization of new zircons during metamorphism (Carson et al. 2002). The zircons grown under metamorphic conditions have lower $\mathrm{Th} / \mathrm{U}$, typically lower than 0.1 , whereas the magmatic zircons have higher $\mathrm{Th} / \mathrm{U}$ ratios $0.18-0.47$ (Rubatto 2002). However, Wang et al. (2011) demonstrate a huge variation in the $\mathrm{Th} / \mathrm{U}$ in the granitic rocks (0.1-3.79) and in the intermediate rocks (0.02$6.82)$. Zircon growth with high $\mathrm{Th} / \mathrm{U}$ ratios $(>1)$ has also been reported during UHT metamorphism (Carson et al. 2002). The Th/U ratio for the gneissic samples from the KGB and the KSB show high values $(0.14-1.8)$ on average (tables $3-8)$. We interpret the concordant ages obtained from the KGB and $\mathrm{KSB}$ to be representing relict magmatic zircons (representing either original igneous protolith or detrital), which has the $\mathrm{U}-\mathrm{Pb}$ system reset by the tectonothermal events.

The NKSB, EGMB, KGB are important pieces in the reconstruction of the Proterozoic history of the Indian continent and its part in the global tectonic framework and supercontinent cycle (Meert 2012; Nance et al. 2013; Meert et al. 2017). The results presented in this contribution demonstrate that the samples of KGB and northern NKSB are unique in terms of their zircon $\mathrm{U}-\mathrm{Pb}$ geochronology suggesting a distinct, tectonothermal history relative to each other (figure 7). The different rock samples were collected from localities currently in close proximity (within $\sim 50 \mathrm{~km}$ of one another) from the eastern part of KGB and the northern Khammam schist belt of the NKSB.

The granite samples from the KGB are $\sim 2400$ Ma old (intercept age of EHV596 is $2428 \pm 16 \mathrm{Ma}$ and the schistose granite sample (EHV593) show a weighted average age of $2480 \pm 31 \mathrm{Ma}$ ). The interpreted age of 2400-2500 Ma for the granite within the KGB is in good agreement with the previously reported $\mathrm{Rb}-\mathrm{Sr}$ whole rock age result of $2490 \pm$ 115 Ma (Crawford 1969). This Late Archaean event is also reported as a metamorphic imprint in the zircons of granulites from KGB by Santosh et al. (2004). However, Rajesham et al. (1993) consider the $2.5 \mathrm{Ga}$ event to represent peak metamorphism of the KGB rocks to granulite grade. Recently, Prakash et al. (2017) date this peak metamorphism earlier than the granite event at $2604 \pm 25$ Ma.

The two samples of gneisses (EHV597 and EHV592) from the KGB were collected from the same area and combined constitute a prominent 1560-1600 Ma age group. The $1000 \mathrm{Ma}$ old event recorded in EHV597 is not evident from the concordant ages in EHV592 (figure 4). Combining the results from all four samples, the KGB is interpreted to record metamorphic resetting at 


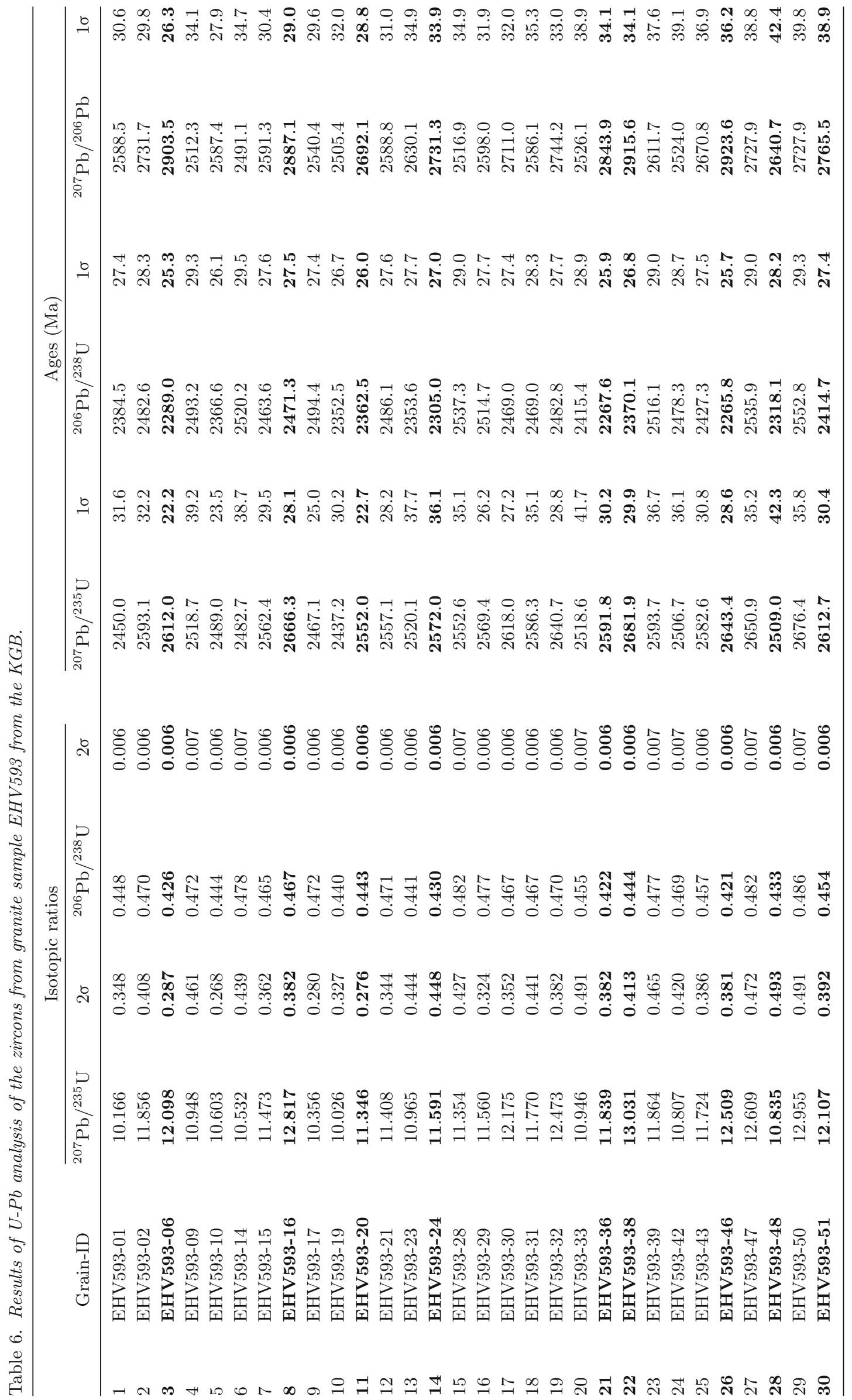


Table 6. (Continued.)

\begin{tabular}{|c|c|c|c|c|c|c|c|}
\hline & $\begin{array}{c}\text { Disc } \\
(\%)\end{array}$ & $\begin{array}{c}\mathrm{Pb} \\
(\mathrm{ppm})\end{array}$ & $\begin{array}{c}\text { Th } \\
(\mathrm{ppm})\end{array}$ & $\begin{array}{c}\mathrm{U} \\
(\mathrm{ppm})\end{array}$ & $\mathrm{Th} / \mathrm{U}$ & $\begin{array}{l}\text { Accepted } \\
\text { age }(\mathrm{Ma})\end{array}$ & $1 \sigma$ \\
\hline 1 & 7.9 & 90.87 & 195.91 & 204.7 & 1.0 & 2384.5 & 27.38 \\
\hline 2 & 9.1 & 63.38 & 114.81 & 143.21 & 0.8 & 2482.6 & 28.26 \\
\hline 3 & 21.2 & 317.17 & 199.27 & 791.13 & 0.3 & NA & NA \\
\hline 4 & 0.8 & 48.68 & 97.62 & 109.76 & 0.9 & 2493.2 & 29.27 \\
\hline 5 & 8.5 & 522.28 & 707.7 & 1253.96 & 0.6 & 2489 & 23.49 \\
\hline 6 & -1.2 & 55.26 & 109.32 & 123.24 & 0.9 & 2520.2 & 29.49 \\
\hline 7 & 4.9 & 96.67 & 132.98 & 221.67 & 0.6 & 2463.6 & 27.59 \\
\hline 8 & 14.4 & 117.23 & 167.32 & 267.89 & 0.6 & NA & NA \\
\hline 9 & 1.8 & 181.57 & 73.3 & 453.02 & 0.2 & 2467.1 & 25.04 \\
\hline 10 & 6.1 & 87.43 & 226.87 & 212.16 & 1.1 & 2352.5 & 26.73 \\
\hline 11 & 12.2 & 378.8 & 90.61 & 914.89 & 0.1 & NA & NA \\
\hline 12 & 4.0 & 151.35 & 131.88 & 344.05 & 0.4 & 2486.1 & 27.63 \\
\hline 13 & 10.5 & 49.74 & 96.45 & 120.83 & 0.8 & 2353.6 & 27.74 \\
\hline 14 & 15.6 & 57.47 & 120.88 & 143.15 & 0.8 & NA & NA \\
\hline 15 & -0.8 & 69.04 & 155.25 & 153.44 & 1.0 & 2537.3 & 28.96 \\
\hline 16 & 3.2 & 220.26 & 224.4 & 495 & 0.5 & 2569.4 & 26.19 \\
\hline 17 & 8.9 & 208.71 & 559.82 & 479.64 & 1.2 & 2618 & 27.15 \\
\hline 18 & 4.5 & 70.55 & 319.66 & 162.22 & 2.0 & 2469 & 28.31 \\
\hline 19 & 9.5 & 168.48 & 217.15 & 384.89 & 0.6 & 2482.8 & 27.67 \\
\hline 20 & 4.4 & 44.95 & 91.89 & 106.17 & 0.9 & 2415.4 & 28.85 \\
\hline 21 & 20.3 & 126.73 & 115.28 & 322.98 & 0.4 & NA & NA \\
\hline 22 & 18.7 & 275.75 & 410.31 & 667.02 & 0.6 & NA & NA \\
\hline 23 & 3.7 & 70.03 & 177.9 & 157.7 & 1.1 & 2516.1 & 29.02 \\
\hline 24 & 1.8 & 71.18 & 286.19 & 163.37 & 1.8 & 2478.3 & 28.68 \\
\hline 25 & 9.1 & 158.12 & 258.53 & 372.21 & 0.7 & 2427.3 & 27.47 \\
\hline 26 & 22.5 & 273.73 & 230.1 & 699.9 & 0.3 & NA & NA \\
\hline 27 & 7.0 & 85.92 & 127.79 & 192.02 & 0.7 & 2535.9 & 29.04 \\
\hline 28 & 12.2 & 40.94 & 108.75 & 101.93 & 1.1 & NA & NA \\
\hline 29 & 6.4 & 90.93 & 135.15 & 201.68 & 0.7 & 2552.8 & 29.27 \\
\hline 30 & 12.7 & 249.43 & 250.61 & 591.79 & 0.4 & NA & NA \\
\hline
\end{tabular}

NA: Not applicable. Bold data are rejected and not utilised in the analysis.

Discordance is defined as $1-\left({ }^{206} \mathrm{~Pb} /{ }^{238} \mathrm{U}\right.$ Age $\div{ }^{207} \mathrm{~Pb} /{ }^{206} \mathrm{~Pb}$ Age $)$.

$\sim 1600$ Ma with a later tectonothermal event at $\sim 1000 \mathrm{Ma}$. The granite intrusions at 2400-2500 Ma most likely form part of the regional Late Archaean granite magmatism within the Dharwar craton (Jayananda et al. 2013). The 3100 and $2600 \mathrm{Ma}$ ages reported by Santosh et al. (2004) for the western KGB could not be reproduced in our samples. This suggests that the 1600 Ma event was intense enough to reset the $\mathrm{U}-\mathrm{Pb}$ system in the zircons completely. However, we report a 1000 Ma Grenvillian tectonothermal event in the KGB, which was hitherto unreported.

Santosh et al. (2004), based on the absence of the Mesoproterozoic tectonothermal event in the KGB and the prominence of the $1600 \mathrm{Ma}$ event in the $\mathrm{BGB}$, proposed that the KGB and BGB evolved under different $\mathrm{P}-\mathrm{T}$ conditions at different times. We report an intense $1600 \mathrm{Ma}$ event from the southeastern part of the KGB and propose that the two granulite belts are probably affected by the same tectonic event. The $1600 \mathrm{Ma}$ event marks the fragmentation of the craton and the development of the $\mathrm{P}-\mathrm{G}$ valley (Chaudhuri et al. 2012). The $\sim 1600$ Ma event was also identified in detrital zircon populations from the Sullavai Group of the $\mathrm{P}-\mathrm{G}$ rift (Joy et al. 2015). We note that Basu and Bickford (2015) consider the glauconite ages reported from the Somanpalli Group and Pandikunta Limestone to be unreliable (cf., Conrad et al. 2011). They consider the deposition of Somanpalli rocks to have started after the eastern Dharwar-Bastar amalgamation at $\sim 1600 \mathrm{Ma}$, with deformation being due to the continued crustal shortening that followed craton amalgamation. 


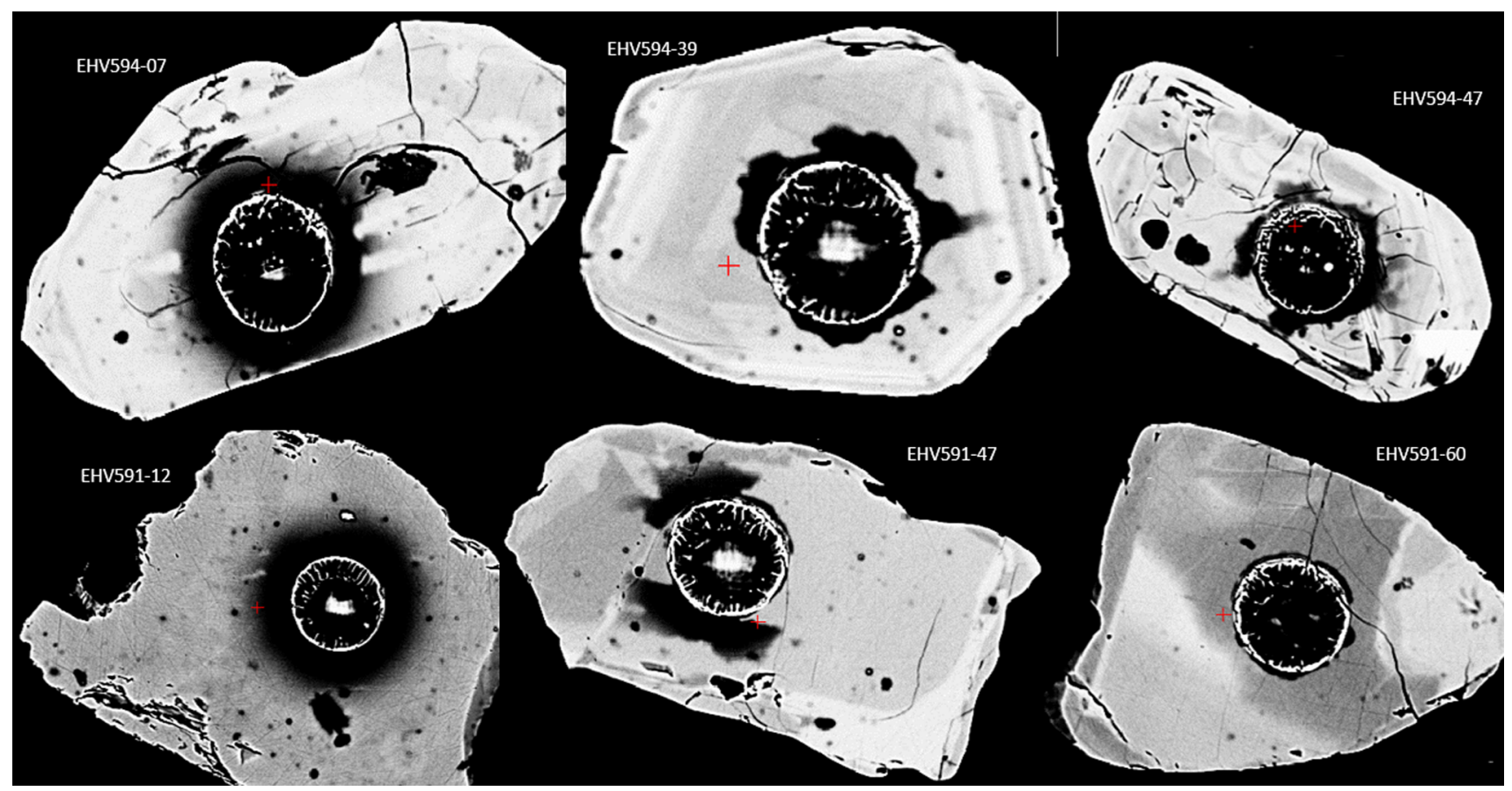

Figure 5. Examples of back scatter electron Z images captured using a CAMECA SX100 Electron Probe Micro Analyser for samples from the Khammam schist belt. Ablation spots are $35 \mu \mathrm{m}$ in diameter and can be seen as circular holes.

The present report of a 1000 Ma tectonothermal event from the gneissic rocks of the KGB is contrary to Santosh et al. (2004). The presence of this Grenvillian age in the KGB, which is very prominent in the EGMB, highlights that both the KGB and EGMB were part of the global Grenvillian orogenic belt during the Rodinia supercontinent formation (figure 7). Unfortunately, the age of reassembly of the Dharwar and Bastar cratons cannot be constrained. Based on geological and structural analysis, it was suggested that suturing occurred subsequently to Mulug Group deposition (1565 Ma), but prior to Albaka and Sullavai Group deposition (Chaudhuri et al. 2012). The age of the Sullavai Group has recently been shown to be younger than $710 \mathrm{Ma}$ (Joy et al. 2015). The 1000 Ma event reported herein is thus best interpreted as the age of 'Grenvillian' orogeny by which the Dharwar and Bastar cratons were reassembled.

It has been previously demonstrated that the NKSB records multiple deformation and metamorphism cycles, as well as granitic and alkaline intrusive magmatism (Saha et al. 2015 and references therein). Our NKSB samples represent unique and contrasting geochronological signatures to the samples from the KGB including the granite. The samples EHV594 and EHV591 show presence of Archaean zircons. The 3100-3250 Ma ages, which are interpreted as relict zircons (either representing protolith or detrital zircons as the nature of the protolith of the gneisses sampled, whether igneous or sedimentary has not been established during this study) of the Khammam schist belt of the NKSB (figures 6 and 7).

For sample EHV594, the prominent age range is $\sim 1800 \mathrm{Ma}$. This age range is not very apparent in EHV591, where $2400 \mathrm{Ma}$ age is most prominent. Sample EHV594 also shows the 2400-2700 Ma age range, though not as pronounced as recorded in EHV591 (figure 6). The $1900 \mathrm{Ma}$ age has also been reported previously in the $\mathrm{Sm}-\mathrm{Nd}$ isochron age of the gabbro intrusions (Vadlamani 2010) and the ${ }^{207} \mathrm{~Pb} /{ }^{206} \mathrm{~Pb}$ zircon evaporation ages of andesitic rocks (Vadlamani et al. 2012) in the Vinjamuru Group, and the $\mathrm{U}-\mathrm{Pb}$ xenotime age from the Udaigiri Group (Das et al. 2015). The KOC with an age range of 1850-1900 Ma (Vadlamani 2010; Vijaya Kumar et al. 2010) is postulated to represent orogenic accretion that led to Columbia supercontinent assembly (Saha et al. 2015).

Both EHV591 and EHV594 record a ca. 500 Ma age from a few zircon grains. The $500 \mathrm{Ma}$ event is also recorded in the amphibolites from the Khammam schist belt (Okudaira et al. 2001), the mylonites of the Vinikonda Granite 


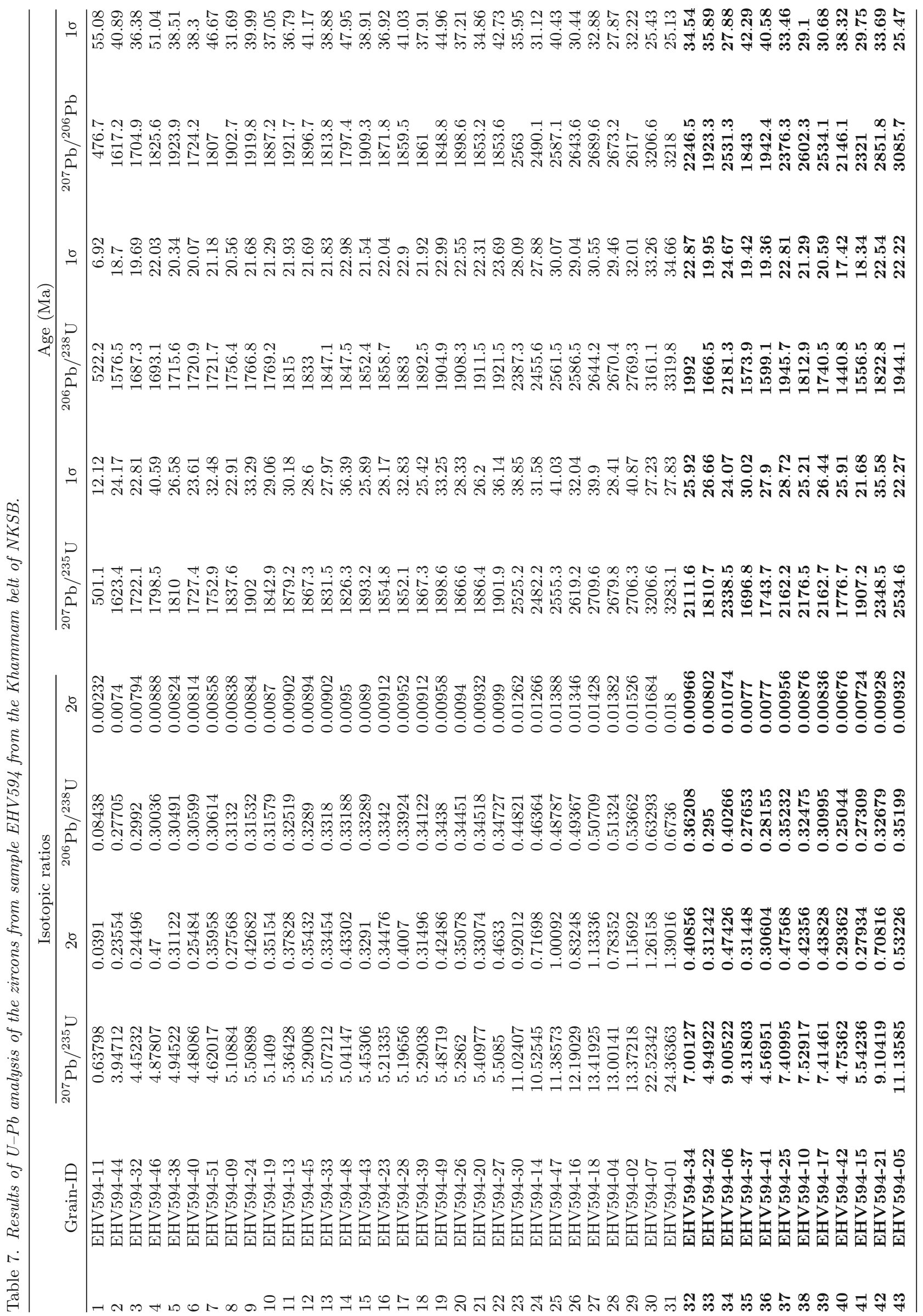


Table 7. (Continued.)

\begin{tabular}{|c|c|c|c|c|c|c|c|}
\hline & $\begin{array}{l}\text { Disc } \\
(\%)\end{array}$ & $\begin{array}{c}\mathrm{Pb} \\
(\mathrm{ppm})\end{array}$ & $\begin{array}{c}\mathrm{Th} \\
(\mathrm{ppm})\end{array}$ & $\begin{array}{c}\mathrm{U} \\
(\mathrm{ppm})\end{array}$ & $\mathrm{Th} / \mathrm{U}$ & $\begin{array}{l}\text { Accepted } \\
\text { age }(\mathrm{Ma})\end{array}$ & $1 \sigma$ \\
\hline 1 & -9.5 & 37.53 & 132.49 & 484 & 0.3 & 522.2 & 25.13 \\
\hline 2 & 2.5 & 294.57 & 438.41 & 1156.72 & 0.4 & 1576.5 & 18.7 \\
\hline 3 & 1.0 & 404.96 & 2834.73 & 1472.53 & 1.9 & 1687.3 & 19.69 \\
\hline 4 & 7.3 & 31.81 & 53.2 & 115.21 & 0.5 & 1693.1 & 22.03 \\
\hline 5 & 10.8 & 144.87 & 217.51 & 516.88 & 0.4 & 1715.6 & 20.34 \\
\hline 6 & 0.2 & 355.16 & 219.86 & 1262.73 & 0.2 & 1720.9 & 20.07 \\
\hline 7 & 4.7 & 68.88 & 241.29 & 244.75 & 1.0 & 1721.7 & 21.18 \\
\hline 8 & 7.7 & 114.84 & 201.38 & 398.96 & 0.5 & 1756.4 & 20.56 \\
\hline 9 & 8.0 & 50.99 & 82.57 & 175.92 & 0.5 & 1766.8 & 21.68 \\
\hline 10 & 6.3 & 67.79 & 169.02 & 233.57 & 0.7 & 1769.2 & 21.29 \\
\hline 11 & 5.6 & 61.67 & 110.36 & 206.35 & 0.5 & 1815 & 21.93 \\
\hline 12 & 3.4 & 124.52 & 117.91 & 411.87 & 0.3 & 1833 & 21.69 \\
\hline 13 & -1.8 & 111.54 & 127.45 & 365.73 & 0.3 & 1847.1 & 21.83 \\
\hline 14 & -2.8 & 49.75 & 71.27 & 163.08 & 0.4 & 1847.5 & 22.98 \\
\hline 15 & 3.0 & 226.01 & 718.14 & 738.6 & 1.0 & 1852.4 & 21.54 \\
\hline 16 & 0.7 & 82.95 & 144.37 & 270.04 & 0.5 & 1858.7 & 22.04 \\
\hline 17 & -1.3 & 54.61 & 98.07 & 175.14 & 0.6 & 1883 & 22.9 \\
\hline 18 & -1.7 & 201.79 & 191.16 & 643.39 & 0.3 & 1892.5 & 21.92 \\
\hline 19 & -3.0 & 84.47 & 92.74 & 267.28 & 0.3 & 1904.9 & 22.99 \\
\hline 20 & -0.5 & 81.62 & 98.37 & 257.77 & 0.4 & 1908.3 & 22.55 \\
\hline 21 & -3.1 & 102.83 & 156.99 & 324.14 & 0.5 & 1911.5 & 22.31 \\
\hline 22 & -3.7 & 46.73 & 51.04 & 146.39 & 0.3 & 1921.5 & 32.01 \\
\hline 23 & 6.9 & 65.72 & 205.95 & 159.52 & 1.3 & 2387.3 & 28.09 \\
\hline 24 & 1.4 & 87.74 & 159.22 & 205.91 & 0.8 & 2455.6 & 27.88 \\
\hline 25 & 1.0 & 74.34 & 85.31 & 165.76 & 0.5 & 2561.5 & 30.07 \\
\hline 26 & 2.2 & 89.97 & 106.08 & 198.3 & 0.5 & 2586.5 & 29.04 \\
\hline 27 & 1.7 & 51.81 & 158.41 & 111.16 & 1.4 & 2644.2 & 30.55 \\
\hline 28 & 0.1 & 103.73 & 281.81 & 219.93 & 1.3 & 2673.2 & 27.87 \\
\hline 29 & -5.8 & 44.02 & 61.7 & 89.27 & 0.7 & 2769.3 & 25.43 \\
\hline 30 & 1.4 & 158.11 & 137.87 & 271.81 & 0.5 & 3206.6 & 25.43 \\
\hline 31 & -3.2 & 151.38 & 96.26 & 244.54 & 0.4 & 3218 & 25.13 \\
\hline 32 & 11.3 & 184.95 & 305.63 & 555.73 & 0.5 & NA & NA \\
\hline 33 & 13.4 & 89.59 & 160.84 & 330.41 & 0.5 & NA & NA \\
\hline 34 & 13.8 & 136.77 & 483.01 & 369.59 & 1.3 & NA & NA \\
\hline 35 & 14.6 & 62.5 & 151.36 & 245.87 & 0.6 & NA & NA \\
\hline 36 & 17.7 & 97.44 & 348.92 & 376.5 & 0.9 & NA & NA \\
\hline 37 & 18.1 & 184.31 & 453.93 & 569.18 & 0.8 & NA & NA \\
\hline 38 & 30.3 & 177.73 & 1300.79 & 595.47 & 2.2 & NA & NA \\
\hline 39 & 31.3 & 93.46 & 286.22 & 328.07 & 0.9 & NA & NA \\
\hline 40 & 32.9 & 260.38 & 813.44 & 1131.06 & 0.7 & NA & NA \\
\hline 41 & 32.9 & 224.41 & 216.22 & 894.09 & 0.2 & NA & NA \\
\hline 42 & 36.1 & 59.36 & 225.81 & 197.62 & 1.1 & NA & NAS \\
\hline 43 & 37.0 & 186.67 & 71.88 & 577.07 & 0.1 & NA & NA \\
\hline
\end{tabular}

$\overline{\mathrm{NA}}$ - Not Applicable - Bold data are rejected and not utilised in the analysis. Discordance is defined as $1-\left({ }^{206} \mathrm{~Pb} /{ }^{238} \mathrm{U}\right.$ Age $\div{ }^{207} \mathrm{~Pb} /{ }^{206} \mathrm{~Pb}$ Age) .

(Dobmeier et al. 2006) and from pegmatites in the Nellore schist belt (Ghosh et al. 1994). Combining the results from the two samples (EHV591 and EHV594), we interpret that the Khammam belt of NKSB represents Archaean protolith (>2600 Ma), which has been affected by four major tectonothermal events which has affected/reset the $\mathrm{U}-\mathrm{Pb}$ geo-chronometer in zircons. The first event at 2500-2600 Ma could be associated with the first amalgamation of the NKSB with the Dharwar craton, as indicated by the granite event in the KGB and the widespread granitic event in the Dharwar craton (Jayananda et al. 2013). This event is also represented by granite magmatism and zircon rim ages in the KGB (Santosh et al. 2004). We propose that the terranes were juxtaposed at 2600-2500 Ma to form an integral part of proto-India. The 1800-1900 Ma event identified 


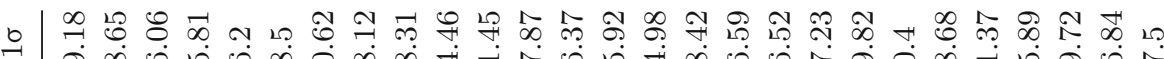

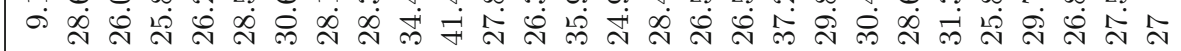

త

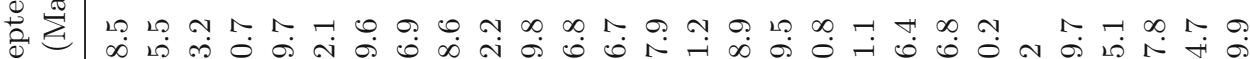
○ D

๘

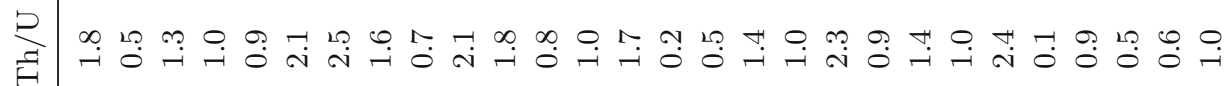

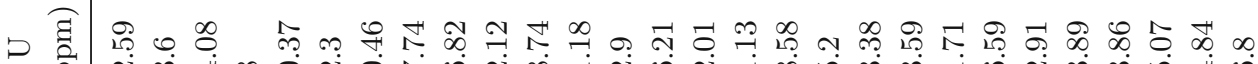

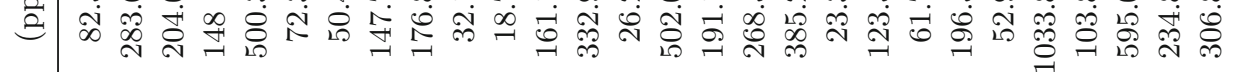

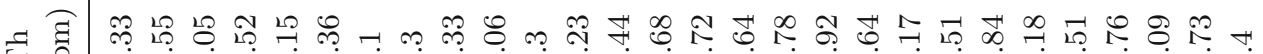

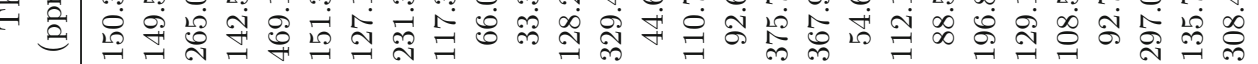

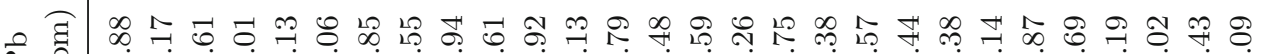

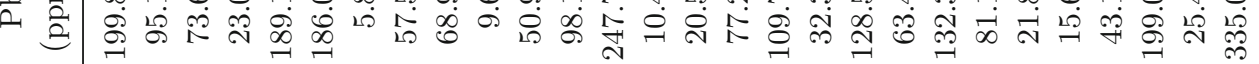

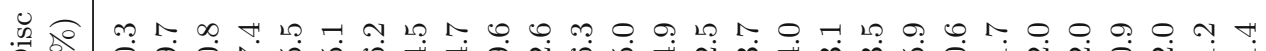

苟

寻

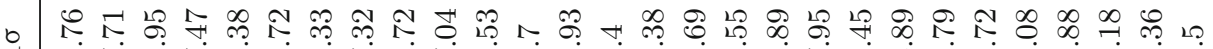

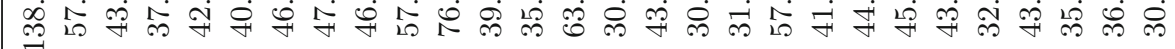

次

ฐँ

है

运

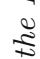

है

ते

(1)

है

aे

垔

ㄴ

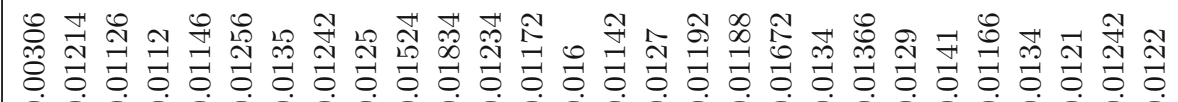

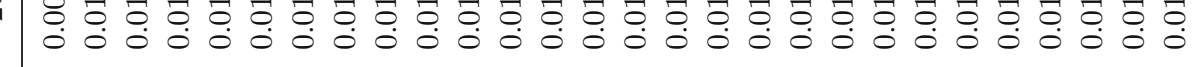

붕

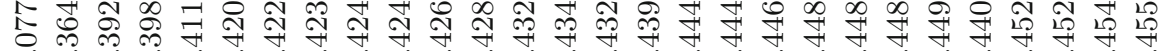

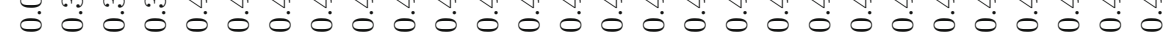

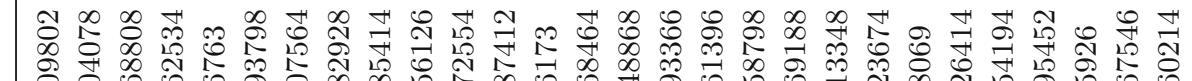

ง

ㅁำ

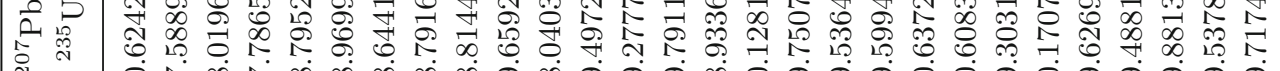

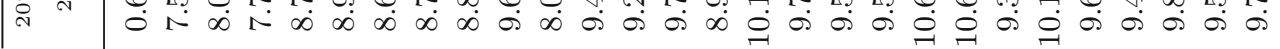

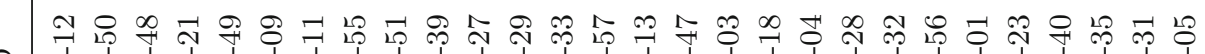

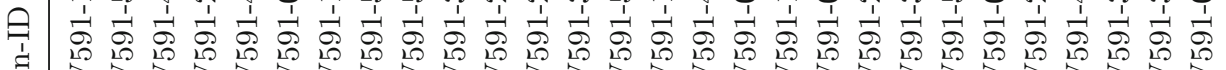




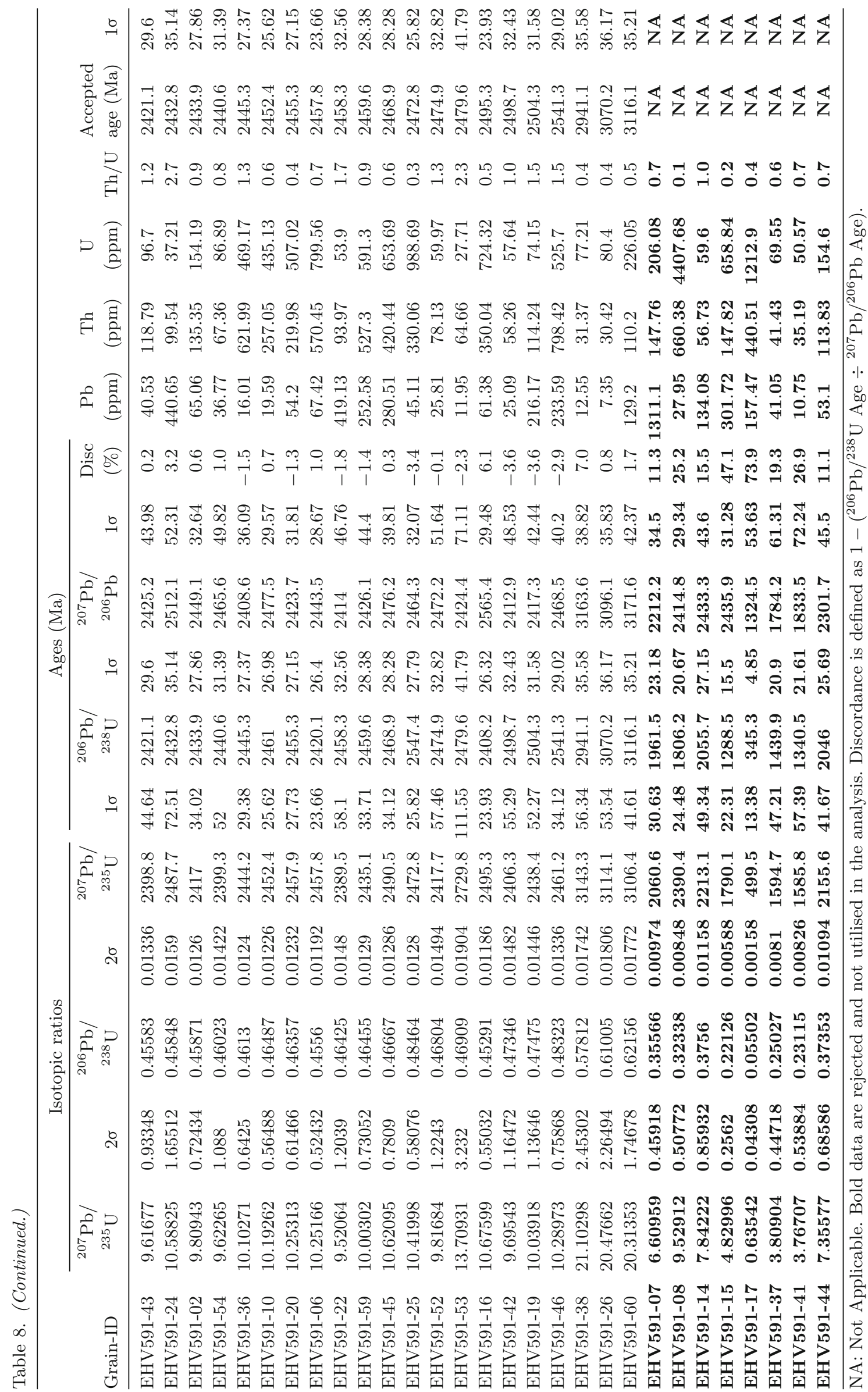



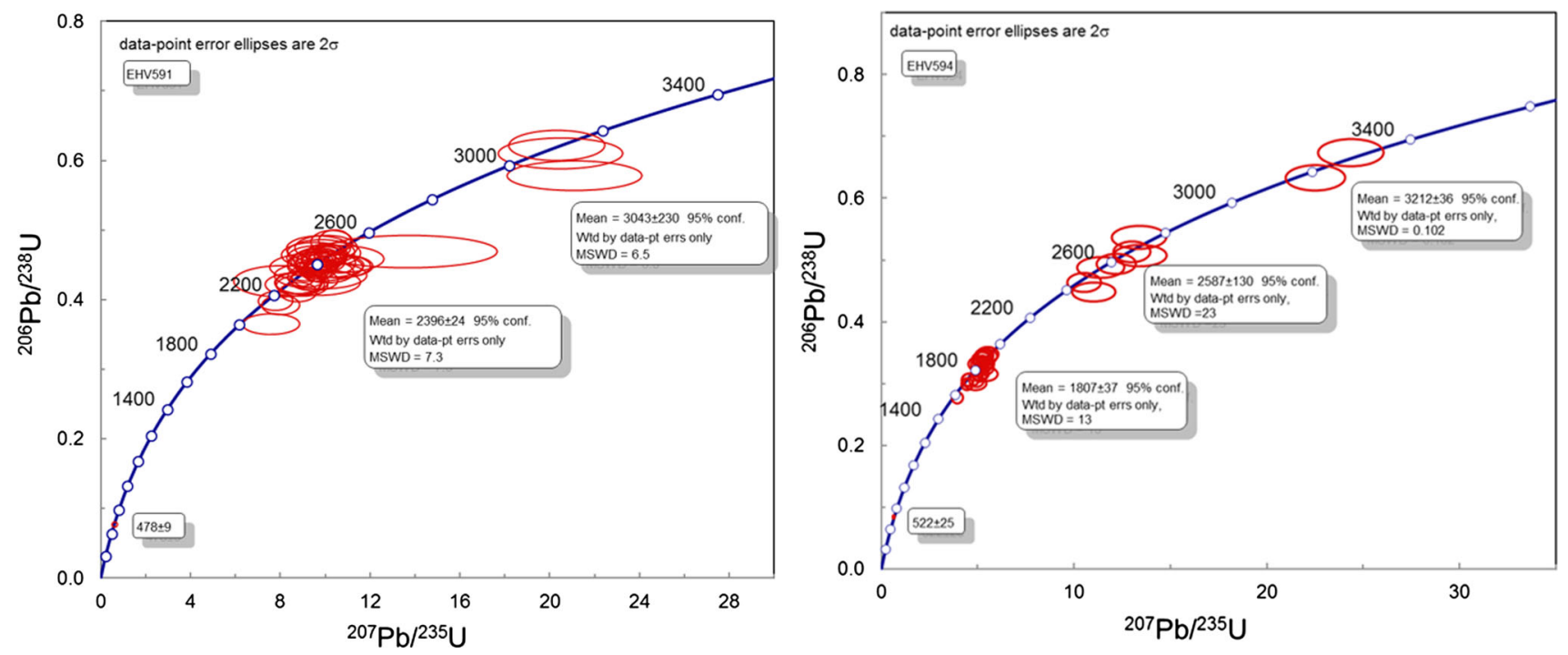

Figure 6. U-Pb concordia diagram of zircons from the Khammam schist belt of NKSB.
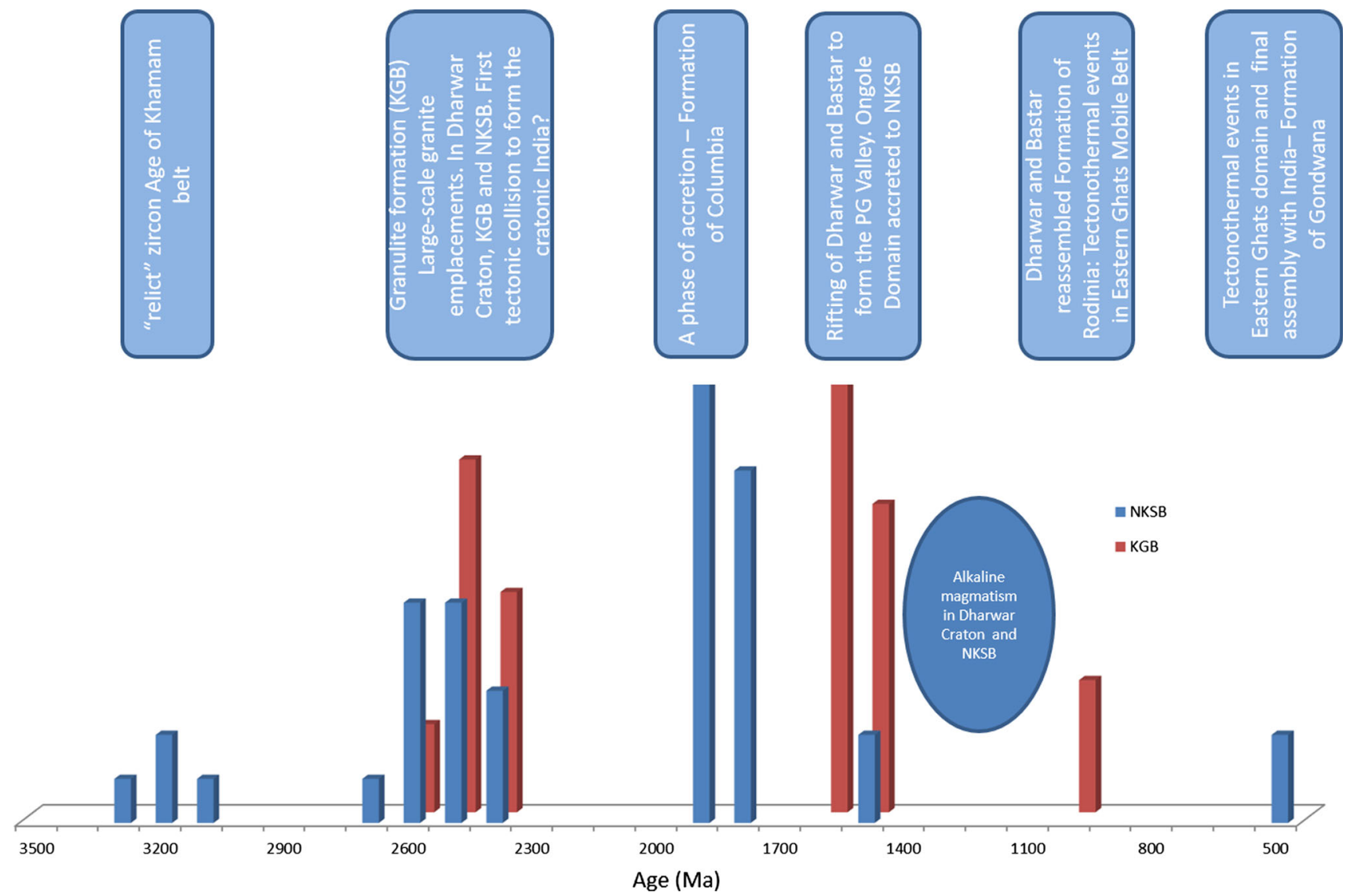

Figure 7. Summary of age groups obtained in the study with regional events. The height of the individual bars is proportional to the number of grains within that age group.

in this study, combined with previously reported events from the Nellore schist belt (Vadlamani 2010; Vadlamani et al. 2012; Das et al. 2015), support another continental accretion event in the eastern part of the southern Indian craton as proposed by Saha et al. (2015). The $\sim 1600 \mathrm{Ma}$ event is considered to represent suturing of the Ongole domain with the Nellore schist belt (Bose et al. 2011; Vijaya Kumar et al. 2011; Henderson et al. 2013) and this event is evident in sample 
EHV594 (figure 6). The $\sim 1000 \mathrm{Ma}$ event from the NKSB (Yoshida et al. 1996; Okudaira et al. 2001) was not identified in the present study. However, zircons from the NKSB show evidence of the $\sim 500$ Ma Pan-African event that led to the formation of Gondwana (figures 6 and 7).

\section{Conclusions}

The northern part of the Nellore-Khammam schist belt known as the Khammam schist belt, and the Karimnagar granulite belt, which are juxtaposed at a high angle to each other are unique in terms of their tectonothermal evolution, as recorded by $\mathrm{U}-\mathrm{Pb}$ zircon age patterns.

Southern India has been affected by multiple events of rifting and collision-accretion throughout its Proterozoic history (see also Basu and Bickford 2015; Saha et al. 2015). The present study indicates that the Khammam schist belt and the northern part of the NKSB probably formed part of cratonic India by about 2500 Ma. The Dharwar and Bastar cratons amalgamation was initiated at $\sim 2600$ Ma with the formation of the granulites and culminating with the emplacement of the granites at $\sim 2400$ Ma. The schist belt has experienced another orogenic accretion at about 1900 Ma probably assigned to the formation of Columbia. The Dharwar and Bastar cratons separated to form the $\mathrm{P}-\mathrm{G}$ valley at $\sim 1600 \mathrm{Ma}$ along with the metamorphic resetting of zircons within the KGB and BGB granulites and gneisses. During this same time period $(\sim 1600 \mathrm{Ma})$, at an orthogonal direction to $\mathrm{P}-\mathrm{G}$ valley, accretion tectonics would have been ongoing whereby the Ongole domain was accreted to the NKSB (Henderson et al. 2013). The P-G valley area inverted to be under a compressional regime, resulting in closure of the basin and the reassembly of the Dharwar and Bastar cratons at about $1000 \mathrm{Ma}$, which could be linked to the formation of Rodinia. The NKSB was affected by the late Pan-African tectonothermal event at ca. 500 Ma that possibly marked the final episode of its assembly with the Eastern Ghats province of the EGMB, since then forming part of the present day Indian subcontinent.

Our study highlights that plate accretion and rifting events in the eastern part of the Dharwar craton and between the Dharwar and Bastar cratons have been repeated through time with highly complex events. Southern India's present tectonic configuration is the result of multiple tectonic events between 2500 and $500 \mathrm{Ma}$, which occurred in different areas and at different times, which can potentially be linked to the formation and dispersal of three supercontinents.

\section{Acknowledgements}

We thank the management of De Beers Exploration for the permission to publish the data. Two anonymous reviewers are thanked for valuable comments and suggestions that helped us to improve this manuscript. SJ would like to thank Andrew Macdonald for his edits and valuable comments.

\section{References}

Acharyya S K 2003 A plate tectonic model for Proterozoic crustal evolution of central Indian tectonic zone; Geol. Mag. 7 9-31.

Balasubrhamanyan M N 2006 Geology and tectonics of India: An overview; Int. Assoc. Gondwana Res. Mem. 9.

Basu A and Bickford M E 2015 An alternate perspective of the opening and closing of the intracratonic Purana basins in peninsular India; J. Geol. Soc. India 85 5-25.

Belica M E, Piispa E J, Meert J G, Pesonenc L J, Plado J, Pandit M, Kamenova G D and Celestinoa M 2014 Paleoproterozoic mafic dyke swarms from the Dharwar craton; paleomagnetic poles for India from 2.37-1.88 Ga and rethinking the Columbia supercontinent. Precamb. Res. 244 100-122.

Biswal T K, De Waele B and Ahuja H 2007 Timing and dynamics of the juxtaposition of the Eastern Ghats Mobile Belt against the Bhandara Craton, India: A structural and zircon U-Pb SHRIMP study of the fold-thrust belt and associated nepheline syenite plutons; Tectonics $\mathbf{2 6} 1$ 21.

Bleeker W 2003 The late Archaean record: A puzzle in c. 35 pieces; Lithos 71 99-134.

Bose S, Dunkley D J, Dasgupta S, Das K and Arima M 2011 India-Antarctica-Australia-Laurentia connection in the Paleoproterozoic-Mesoproterozoic revisited: Evidence from new zircon $\mathrm{U}-\mathrm{Pb}$ and monazite chemical age data from the Eastern Ghats Belt, India; Geol. Soc. Am. Bull. 123 2031-2049.

Bradley D C 2011 Secular trends in the geologic record and the supercontinent cycle; Earth-Sci. Rev. 108 16-33.

Carson C J, Ague J J and Coath C D 2002 U-Pb geochronology from Tonagh Island, East Antarctica: Implication for the timing of ultra-high temperature metamorphism of the Napier complex; Precamb. Res. 116 237-263.

Chadwick B, Vasudev V N and Hegde G V 2000 The Dharwar craton, southern India, interpreted as the result of late Archean oblique convergence; Precamb. Res. 99 91-111.

Chalapathi Rao N V and Srivastava R K 2016 Kimberlites, lamproites, lamprophyres, carbonatites, other alkaline rocks and mafic dykes from the Indian Shield: Glimpses of research (2012-2016); Proc. Indian Nat. Sci. Acad. 82 $515-536$. 
Chalapathi Rao N V, Wu F Y, Mitchell R H, Li Q L and Lehmann B 2013 Mesoproterozoic U-Pb ages, trace element and $\mathrm{Sr}-\mathrm{Nd}$ isotopic composition of perovskite from kimberlites of the Eastern Dharwar craton, southern India: Distinct mantle sources and a widespread 1.1 Ga tectonomagmatic event; Chem. Geol. 353 48-64.

Chaudhuri A K and Chanda S K 1991 The Proterozoic basin of Pranhita-Godavari valley: An overview; In: Sedimentary basins of India: Tectonic context (eds) Tandon S K, Pant C C and Casshyap S B, Ganodaya Prakashan, Nainital, pp. 13-30.

Chaudhuri A K, Deb G K, Patranabis-Deb S and Sarkar S 2012 Paleogeographic and tectonic evolution of the Pranhita-Godavari valley, central India: A stratigraphic perspective; Am. J. Sci. 312 766-815.

Chaudhuri A K, Saha D, Deb G K, Patranabis-Deb S, Mukherjee M K and Ghosh G 2002 The Purana Basins of Southern Cratonic Province of India: A case for mesoproterozoic fossil rifts; Gondwana Res. 5 23-33.

Conrad J E, Hein J R, Chaudhuri A K, Patranabis-Deb S, Mukhopadhyay J, Deb G K and Beukes N J 2011 Constraints on the development of Proterozoic basins in central India from ${ }^{40} \mathrm{Ar} /{ }^{39} \mathrm{Ar}$ analysis of authigenic glauconitic minerals; Geol. Soc. Am. Bull. 123(1/2) 158-167.

Crawford A R 1969 India, Ceylon and Pakistan: New age data and comparisons with Australia; Nature 233 380384.

Das K, Yokoyama K, Chakraborty P P and Sarkar A 2009 Basal tuffs and contemporaneity of the Chattisgarh and Khariar basins based on new dates and geochemistry; $J$. Geol. 117 88-102.

Das S, Shukla D, Bhattacharjee S and Mitra S K 2015 Age constraints of Udayagiri domain of Nellore schist belt by xenotime dating around Pamuru, Prakasam district, Andhra Pradesh; J. Geol. Soc. India 85 289-298.

Dasgupta S, Bose S, Bhowmik S K and Sengupta P 2017 The Eastern Ghats Belt, India, in the context of supercontinent assembly; In: Crustal evolution of India and Antarctica: The supercontinent connection (eds) Pant N C and Dasgupta S, Geol. Soc. London, Spec. Publ. 457 87-104.

Demirer K 2012 U-Pb Baddeleyite ages from mafic dyke swarms in Dharwar Craton, India: Links to an ancient supercontinent; Dissertations in Geology at Lund University, Master's thesis, 308p.

Dharma Rao C V, Santosh M and Wu Y 2011a Mesoproterozoic ophiolitic mélange from the SE periphery of the Indian plate: $\mathrm{U}-\mathrm{Pb}$ zircon ages and tectonic implications; Gondwana Res. 19 384-401.

Dharma Rao C V, Windley B F and Choudhary A K 2011b The Chimalpahad anorthosite complex and associated basaltic amphibolites, Nellore Schist Belt, India: Magma chamber and roof of a Proterozoic island arc; J. Asian Earth Sci. 40 1027-1043.

Dobmeier C and Raith M 2003 Crustal architecture and evolution of the Eastern Ghats Belt and adjacent regions of India; In: Proterozoic east Gondwana: Supercontinent assembly and breakup (eds) Yoshida M, Windley B F and Dasgupta S, Geol. Soc. London, Spec. Publ. 206 $145-168$.

Dobmeier C, Lutke S, Hammerschmidt K and Mezger K 2006 Emplacement and deformation of the Vinukonda meta-granite (Eastern Ghats, India) - Implications for the geological evolution of peninsular India and for Rodinia reconstructions; Precamb. Res. 146 165-178.

French J E and Heaman L M 2010 Precise U-Pb dating of Paleoproterozoic mafic dyke swarms of the Dharwar craton, India: Implications for the existence of the Neoarchean supercraton Sclavia; Precamb. Res. 183 416441.

French J E, Heaman L M, Chacko T and Rivard B 2004 Global mafic magmatism and continental breakup at 2.2 Ga: Evidence from the Dharwar craton, India; Abstracts Geol. Soc. Am. 36 340p.

Friend C R L and Nutman A P 1991 SHRIMP U-Pb geochronology of the Closepet Granite and peninsular gneiss, Karnataka, south India; J. Geol. Soc. India 38 357-368.

Ghosh D, Das J N, Rao A K, Ray Barman T, Kollapuri V K and Sarkar A 1994 Fission-track and K-Ar dating of pegmatite and associated rocks of Nellore schist belt, Andhra Pradesh: Evidence of Middle to Late Proterozoic events; Indian Mineral. 48 95-102.

Halls H C, Kumar A, Srinivasan R and Hamilton M A 2007 Paleomagnetism and $\mathrm{U} / \mathrm{Pb}$ geochronology of easterly trending dykes in the Dharwar Craton, India: Feldspar clouding, radiating dyke swarms and the position of India at $2.37 \mathrm{Ga}$; Precamb. Res. 155 47-68.

Hari Prasad B, Okudaira T, Hayasaka Y, Yoshida M and Divi R S 2000 Petrology and geochemistry of amphibolites from the Nellore-Khammam schist belt, SE India; J. Geol. Soc. India $\mathbf{5 6}$ 67-78.

Henderson B, Collins A, Payne J, Forbes C and Saha D 2013 Geologically constraining India in Columbia: The age, isotopic provenance and geochemistry of the protoliths of the Ongole Domain, Southern Eastern Ghats, India; Gondwana Res. 26 888-906.

Holland T H 1907 The imperial gazetteer of India; 1st edn, Oxford At The Clarendon Press, pp. 50-103.

Jackson S E, Pearson N J, Griffin W L and Belousova E A 2004 The application of laser ablation-inductively coupled plasma-mass spectrometry to in situ $\mathrm{U}-\mathrm{Pb}$ zircon geochronology; Chem. Geol. 211 47-69.

Jayananda M, Kano T, Peucat J J and Channabasappa S 2008 3.35 Ga komatiite volcanism in the western Dharwar craton, southern India: Constraints from $\mathrm{Nd}$ isotopes and whole rock geochemistry; Precamb. Res. 162 160179.

Jayananda M, Peucat J J, Chardon D, Krishna Rao B, Fanning C M and Corfu F 2013 Neoarchean greenstone volcanism and continental growth, Dharwar craton, southern India: Constraints from SIMS U-Pb zircon geochronology and Nd isotopes; Precamb. Res. 227 55-76.

Joy S, Jelsma H, Armstrong R and Tappe S 2015 SHRIMP U-Pb zircon provenance of the Sullavai Group of Pranhita-Godavari basin and Bairenkonda formation of Cuddapah basin, with implications for the southern Indian Proterozoic tectonic architecture; J. Asian Earth Sci. $111827-839$.

Kale V S and Phansalkar V G 1991 Purana basins of peninsular India: A review; Basin Res. 3 1-36.

Korhonen F J, Saw A K, Clark C, Brown M and Bhattacharya S 2011 New constraints on UHT metamorphism in the Eastern Ghats Province through the application 
of phase equilibria modelling and in situ geochronology; Gondwana Res. 20 764-781.

Kovach V P, Simmat R, Rickers K, Berezhnaya N G, Salnikova E B, Dobmeier C, Raith M M, Yakovleva S Z and Kotov A B 2001 The Western Charnockite Zone of the Eastern Ghats Belt, India - an independent crustal province of Late Archaean (2.8 Ga) and Palaeoproterozoic (1.7-1.6 Ga) terrains; Gondwana Res. 4 666-667.

Kumar A, Heaman L M and Manikyamba C 2007 Mesoproterozoic kimberlites in South India: A possible link to $1.1 \mathrm{Ga}$ global magmatism; Precamb. Res. 154192 204.

Kumar A, Hamilton M A and Halls H C 2012a A Paleoproterozoic giant radiating dyke swarm in the Dharwar Craton, southern India; Geochem. Geophys. Geosyst. 13(2), https://doi.org/10.1029/2011GC003926.

Kumar A, Nagaraju E, Besse J and Bhaskar Rao Y J 2012b New age, geochemical and paleomagnetic data on a $2.21 \mathrm{Ga}$ dyke swarm from south India: Constraints on Paleoproterozoic reconstruction; Precamb. Res. 220-221 123-138.

Kumar A, Parashuramulu V and Nagaraju E 2015 A 2082 Ma radiating dyke swarm in the Eastern Dharwar Craton, southern India and its implications to Cuddapah basin formation; Precamb. Res. 266 490-505.

Ludwig K R 2001 Isoplot 3.0, a geochronological toolkit for Microsoft Excel; Special Publication No. 4, Berkeley Geochronology Center, Berkeley, California, pp. 1-70.

Ma M, Wan Y, Santosh M, Xu Z, Xie H, Dong C, Liu D and Guo C 2012 Decoding multiple tectonothermal events in zircon from single rock samples: SHRIMP zircon U$\mathrm{Pb}$ data from the late Neoarchean rocks of Daquingshan, North China Craton; Gondwana Res. 22 810-827.

Mallikarjuna R J, Bhattacharji S, Rao M N and Hermes O D $1995{ }^{40} \mathrm{Ar}-{ }^{39} \mathrm{Ar}$ ages and geochemical characteristics of dolerite dykes around the Proterozoic Cuddapah basin, South India; In: Mafic dyke swarms of Peninsular India (ed.) Devaraju T C, Geol. Soc. India. Memoir 33 307328.

Malone S J, Meert J G, Banerjee D M, Pandit M K, Tamrat E, Kamenov G D, Pradhan V R and Sohl L E 2008 Paleomagnetism and detrital zircon geochronology of the upper Vindhyan Sequence, Son Valley and Rajasthan, India: A ca. $1000 \mathrm{Ma}$ closure age for the Purana basins; Precamb. Res. 164 137-159.

Meert J G 2012 What's in a name? The Columbia (Paleopangaea/Nuna) supercontinent; Gondwana Res. 21 987-993.

Meert J G, Pandit M K, Pivarunas A, Katusin K and Sinha A K 2017 India and Antarctica in the Precambrian: A brief analysis; In: Crustal evolution of India and Antarctica: The supercontinent connection (eds) Pant N C and Dasgupta S, Geol. Soc. London, Spec. Publ. 457, https:// doi.org/10.1144/SP457.13.

Moeen S 1998 P-T estimates from the Nellore schist belt (India) and evidence for superimposed metamorphic events; Geol. J. 33 1-15.

Mukhopadhyay D and Basak K 2009 The Eastern Ghats Belt-Polycyclic granulite terrane; J. Geol. Soc. India 73 489-518.

Murthy Y G K, Baburao V, Guptasarma D, Rao J M and Rao M N 1987 Tectonic, petrochemical and geophysical studies of mafic dyke swarms around the Proterozoic Cud- dapah basin, south India; In: Mafic dyke swarms (eds) Halls H C and Fahrig W F, Geol. Assoc. Canada, Spec. Publ. 34 303-316.

Nance R D and Murphy J B 2013 Origin of the supercontinent cycle; Geosci. Front. 4 439-448.

Nance D R, Murphy J B and Santosh M 2013 The supercontinent cycle: A retrospective essay; Gondwana Res. 25(1) $4-29$.

Naqvi S M and Rogers J J W 1987 Precambrian Geology of India; Oxford University Press, Oxford.

Naqvi S M, Divakara Rao V and Narain H 1974 The protocontinental growth of the Indian shield and the antiquity of its rift valleys; Precamb. Res. 1(4) 345-389.

Okudaira T, Hamamoto T, Hari Prasad B and Kumar R $2001 \mathrm{Sm}-\mathrm{Nd}$ and $\mathrm{Rb}-\mathrm{Sr}$ dating of amphibolite from the Nellore-Khammam schist belt, SE India: Constraints on the collision of the Eastern Ghats terrane and DharwarBastar craton; Geol. Mag. 138 495-498.

Pandey B K, Gupta J N, Sarma K J and Sastry C A 1997 $\mathrm{Sm}-\mathrm{Nd}, \mathrm{Pb}-\mathrm{Pb}$ and $\mathrm{Rb}-\mathrm{Sr}$ geochronology and petrogenesis of the mafic dyke swarm of Mahbubnagar, South India: Implications for Paleoproterozoic crustal evolution of the Eastern Dharwar Craton; Precamb. Res. 84 181196.

Patranabis-Deb S, Bickford M E, Hill B, Chaudhuri A K and Basu A 2007 SHRIMP ages of zircon in the uppermost tuff in Chattisgarh basin in central India require $\sim 500 \mathrm{Ma}$ adjustment in Indian Proterozoic stratigraphy; J. Geol. 115 407-415.

Pradhan V R, Pandit M K and Meert J G 2008 A cautionary note on the age of the paleomagnetic pole obtained from the Harohalli dyke swarms, Dharwar craton, southern India; In: Indian dykes: Geochemistry, geophysics and geochronology (eds) Srivastava R K, Shivaji C H and Chalapathi Rao N V, Narosa Publication, New Delhi, pp. 339-352.

Prakash D, Chandra Singh P, Tewari S, Joshi M, Frimmel H E, Hokada T and Rakotonandrasana T 2017 Petrology, pseudosection modelling and U-Pb geochronology of silica-deficient $\mathrm{Mg}-\mathrm{Al}$ granulites from the Jagtiyal section of Karimnagar granulite terrane, northeastern Dharwar Craton, India; Precamb. Res. 299 177-194.

Qureshy M N, Krishna Brahmam N, Garde S C and Mathur B K 1968 Gravity anomalies and the Godavari rift, India; Geol. Soc. Am. Bull. 79 1221-1230.

Radhakrishna B P and Naqvi S M 1986 Precambrian continental crust of India and its evolution; J. Geol. 94 145-166.

Rajesham T, Bhaskar Rao Y J and Murti K S 1993 The Karimnagar granulite terrane - a new sapphirine bearing granulite province, south India; J. Geol. Soc. India 4 5159.

Rakotonandrasana T 2017 Petrology, pseudosection modelling and $\mathrm{U}-\mathrm{Pb}$ geochronology of silica-deficient $\mathrm{Mg}-\mathrm{Al}$ granulites from the Jagtiyal section of Karimnagar granulite terrane, northeastern Dharwar Craton, India; Precamb. Res. 299 177-194.

Ramakrishnan M 2003 Craton-mobile belt relations in Southern Granulite Terrain; Geol. Soc. India Memoir $\mathbf{5 0}$ 1-24.

Ramakrishnan M and Vaidyanadhan R 2008 Geology of India; Geological Society of India Bangalore, India. 
Ramam P K and Murty V N 1997 Geology of Andhra Pradesh; Geological Society of India, Bangalore, India.

Rasmussen B, Bose P K, Sarkar S, Banerjee S, Fletcher I R and McNaughton N J 20021.6 Ga U-Pb zircon age for the Chorhat Sandstone, lower Vindhyan, India: Possible implications for early evolution of animals; Geology $\mathbf{3 0}$ 103-106.

Ratre K, De Waele B, Biswal T K and Sinha S 2010 SHRIMP geochronology for the 1450 Ma Lakhna dyke swarm: Its implications for the presence of Eoarchaean crust in the Bastar Craton and 1450-517 Ma depositional age for Purana basin (Kariar), Eastern Indian Peninsula; J. Asian Earth Sci. 39 565-577.

Ray J S, Martin M W, Veizer J and Bowring S A 2002 U-Pb zircon dating and $\mathrm{Sr}$ isotope systematics of the Vindhyan Supergroup, India; Geology 30 131-134.

Rickers K, Mezger K and Raith M M 2001 Evolution of the continental crust in the Proterozoic Eastern Ghats Belt, India and new constraints for Rodinia reconstruction: Implications from $\mathrm{Sm}-\mathrm{Nd}, \mathrm{Rb}-\mathrm{Sr}$ and $\mathrm{Pb}-\mathrm{Pb}$ isotopes; Precamb. Res. 112 183-210.

Robinson P L 1971 A problem of faunal replacement on Permo-Triassic continents; Palaeontology 14 131153.

Rogers J J W 1986 The Dharwar craton and the assembly of peninsular India; J. Geol. 94 129-143.

Rubatto D 2002 Zircon trace element geochemistry: Partitioning with garnet and the link between $\mathrm{U}-\mathrm{Pb}$ ages and metamorphism; Chem. Geol. 184 123-138.

Saha D 2011 Dismembered ophiolites in Paleoproterozoic nappe complexes of Kandra and Gurramkonda, south India; J. Asian Earth Sci. 42 158-175.

Saha D and Mazumder R 2012 An overview of the Palaeoproterozoic geology of Peninsular India, and key stratigraphic and tectonic issues; In: Palaeoproterozoic of India (eds) Mazumder R and Saha D, Geol. Soc. London, Spec. Publ. 365 5-29.

Saha D and Tripathy V 2012 Palaeoproterozoic sedimentation in the Cuddapah basin, south India and regional tectonics - a review; In: Paleoproterozoic of India (eds) Mazumder R and Saha D, Geol. Soc. London, Spec. Publ. 365 159-182.

Saha D and Patranabis-Deb S 2014 Proterozoic evolution of Eastern Dharwar and Bastar cratons, India - an overview of the intracratonic basins, craton margins and mobile belts; J. Asian Earth Sci. 91 230-251.

Saha D, Sain A, Nandi P, Mazumder R and Kar R 2015 Tectonostratigraphic evolution of the Nellore schist belt, southern India, since the Neoarchaean; Geol. Soc. London Memoir 43 269-282.

Saha D, Patranabis-Deb S and Collins A 2016 Proterozoic stratigraphy of southern India cratons and global context; Stratigraphy and Timescales 1 1-59.

Sain A, Saha D, Joy S, Jelsma H and Armstrong R 2017 New SHRIMP age and microstructures from a deformed Atype granite, Kanigiri, Southern India: Constraining the hiatus between orogenic closure and post-orogenic rifting; J. Geol. 125(2) 241-259.

Santosh M, Yokoyama K and Acharyya S K 2004 Geochronology and tectonic evolution of Karimnagar and Bhopalpatnam granulite belts, central India; Gondwana Res. 7 501-518.
Sharma R S 2009 Cratons and fold belts of India; Springer, Berlin.

Sheppard S, Rasmussen B, Zi J W, Somasekhar V, Sarma S D, Mohan R M, Krapež B, Wilde S A and McNaughton N J 2017 Sedimentation and magmatism in the Paleoproterozoic Cuddapah basin, India: Consequences of lithospheric extension; Gondwana Res. 48 153163.

Upadhyay D 2008 Alkaline magmatism along the southeastern margin of the Indian shield: Implications for regional geodynamics and constraints on craton - Eastern Ghats Belt suturing; Precamb. Res. 162 59-69.

Upadhyay D, Gerdes A and Raith M M 2009 Unravelling sedimentary provenance and tectonothermal history of high-temperature metapelites, using zircon and monazite chemistry: A case study from the Eastern Ghats Belt, India; J. Geol. 117 665-683.

Vadlamani R 2010 Palaeoproterozoic (1.9 Ga) extension and breakup along the eastern margin of the Eastern Dharwar Craton, SE India: New Sm-Nd isochron age constraints from anorogenic mafic magmatism in the Neoarchean Nellore greenstone belt; J. Asian Earth Sci. 37 6781.

Vadlamani R, Kröner A, Vasudevan D, Wendt I, Tobschall $\mathrm{H}$ and Chatterjee C 2012 Zircon evaporation ages and geochemistry of metamorphosed volcanic rocks from the Vinjamuru domain, Krishna Province: Evidence for $1.78 \mathrm{Ga}$ convergent tectonics along the southeastern margin of the Eastern Dharwar Craton; Geol. J. 48 293309.

Van Achterbergh E, Ryan C G, Jackson S E and Griffin W L 2001 LA-ICP-MS in the earth sciences: Appendix 3, data reduction software for LA-ICP-MS; In: Short course Mineralogical Association of Canada (ed.) Sylvester P J, pp. 239-243.

Vansutre S and Hari K R 2010 Granulite belts of central India with special reference to the Bhopalpatnam Granulite Belt: Significance in crustal evolution and implications for Columbia supercontinent; J. Asian Earth Sci. 39 794-803.

Vansutre S, Hari K R and Vishwakarma N 2013 Implications of geochemistry in support of Palaeo-Proterozoic tectonothermal evolution of Bhopalpatnam Granulite Belt, Bastar Craton, Central India; J. Geol. Soc. India $81503-513$.

Vijaya Kumar K and Leelanandam C 2008 Evolution of the Eastern Ghats Belt, India: A plate tectonic perspective; J. Geol. Soc. India 72 720-749.

Vijaya Kumar K, Ernst W G, Leelanandam C, Wooden J L and Grove M J 2010 First Paleoproterozoic ophiolite from Gondwana: Geochronologic-geochemical documentation of ancient oceanic crust from Kandra, SE India; Tectonophys. 487 22-32.

Vijaya Kumar K, Leelanandam C and Ernst W G 2011 Formation and fragmentation of the Palaeoproterozoic supercontinent Columbia: Evidence from the Eastern Ghats Granulite Belt, southeast India; Int. Geol. Rev. 53 1297-1311.

Wang Y, Fan W, Zhao G, Ji S and Peng T 2007 Zircon U$\mathrm{Pb}$ geochronology of gneissic rocks in the Yunkai massif and its implication on the Caledonian event in the South China block; Gondwana Res. 12 404-416. 
Wang X, Griffin W L, Chen J, Huang P and Li X 2011 U and $\mathrm{Th}$ contents and $\mathrm{Th} / \mathrm{U}$ ratios of zircons in felsic and mafic magmatic rocks: Improved zircon melt distribution coefficients; Acta Geol. Sinica 85 164-174.

Yoshida M, Bindu R S, Kagami H, Rajesham T, Santosh M and Shirahata H 1996 Geochronologic constraints of granulite terranes of South India and their implications for the Precambrian assembly of Gondwana; J. Southeast Asian Earth Sci. 14 137-147.

Zhang J, Mattinson C G, Meng F, Wan Y and Tung K 2008 Polyphase tectonothermal history recorded in granulitized gneisses from the north Qaidam HP/UHP metamorphic terrane, Western China: Evidence from zircon $\mathrm{U}-\mathrm{Pb}$ geochronology; Geol. Soc. Am. Bull. 120 732-749.

Corresponding editor: N V CHALAPATHI RAO 